Journal of Education and Vocational Research

Vol. 2, No. 5, pp. 162-182, Nov 2011 (ISSN 2221-2590)

\title{
Indian Banking - NEW Vision 2030
}

\author{
R. K. Uppal \\ D.A.V.College, Malout, India \\ rkuppal_mlt@yahoo.com
}

\begin{abstract}
Dynamic changes are taking place in the Indian banking industry. The purpose of this paper is to access and analyze the future of Indian banking in the coming competitive era. With the help of ratio analysis method and various statistical techniques, evaluates the performance of banking industry .In the post second banking reforms era, Indian banks are very fastly changing and ready to face the global challenges. The paper has been divided into two parts, i.e pre-ebanking period and post -ebanking period. The paper concludes that the performance of banks much better in the post ebanking period. Only those banks will survive in future, which are intensively using information technology in day-to-day activities. The present paper highlights the changing face of Indian banks and predicts the future for 2030. Information technology has altered the face of Indian banks and it has positively affected the productivity and profitability of banks. The presence of Indian banks in the global market is continuously increasing.
\end{abstract}

Keywords: Delivery channels, Vision of Indian banks, Globalization of Indian banks, Performance of banks, Future of Indian banks

\section{Introduction}

After the set back of early nineties when the Government of India had to pledge the gold to acquire foreign currency to meet the severe problem of balance of payment temporarily, the Government planned to liberalize the Indian economy and open its door to the foreigners to speed up the development process as a long-term solution for the ailing economy. The economic liberalization move, which was initiated in 1991 when the new government assumed office, has touched all the spheres of national activity. Perhaps the one area where the deregulatory policies had the maximum impact was the banking sector. Until 1991, the banking in India was largely traditional. The bankers were prudent and cautious people who seldom took risks and were content with the normal banking activities i.e. accepting of deposits and lending against them. Labeled as "Agents of Social Change", their outlook was rigidly controlled by the policies of the Government, which were centered more on the alleviation of poverty and the upliftment of the downtrodden. The 1969 and 1980's nationalization of banks, bringing private banks under the state control, had the objective of realizing this government dream. The profitability was a forbidden word in banking business even as late as 1991-92. The banks were established to fulfill social objectives and their performance was evaluated on their 'task fulfillment' initiatives. Lending to the priority sectors, opening of rural branches, achievements in the implementation of Government sponsored schemes and adherence to the policies and programmes of the Government were the parameters considered for judging the performance of a bank.

Indian banking system has made commendable progress in extending its geographical spread and functional reach. The nationalization of banks helped in increasing the number of branches, volume of deposits and ensured wider dispersal of the advances. Despite impressive quantitative achievements in resource mobilization and in extending the credit reach, certain deficiencies have, over the years, crept into the financial system such as decline in the productivity and efficiency of the system, erosion of the profitability of the system, directed lending played a critical role in depressing the profits, directed investments in the form of SLR and CRR hindered income earning capability and potentials, portfolio quality suffered due to political and administrative interference in credit decision-making, increase in cost structure due to technological backwardness, average ratio of capital funds to RWAs remained low which creating problems in international operations and the system remained de-linked from sound international banking practices. Realizing all these ill effects, the efforts were made to bring reforms in the financial system of the country. The seed of the reforms in India were sown by the Narasimham Committee appointed by the RBI under the leadership of M. Narasimham, the former Governor of RBI, to examine the aspects relating to the structure, organization, 
functions and procedures of the financial system and suggest remedial measures. The Committee submitted its reports in November 1991 and thus, began a new chapter in Indian banking. The financial system reforms were based on twin principles of operational flexibility and functional autonomy to enhance the efficiency, productivity and profitability of the financial institutions continuously. It aimed at providing a diversified, efficient and competitive financial system with ultimate objective of improving the efficiency of available resources, increasing the return on investments in promoting an accelerated growth of the real sector of the economy. The specific goals of the reforms were the development of transparent and efficient capital and money markets, promotion of competition through free entry/exit in financial sector, improvement in access of financial savings, improvement of financial health of banks by recapitalizing, restructuring etc. of weaker banks, improvement in the level of managerial competence and quality of human resources, and building up financial institutions and infrastructure relating to supervision, audit, technology and legal framework. In the present scenario, technology is the only factor that can provide the edge to the public sector banks over the private sector banks in providing better and quick services to the customers. After the liberalization and globalization, there have vast changes in thoughts, policy, planning and implementation to bring the real benefit for the banking sector. So the banking scenario in the Indian context is changed to get success according to new changes, one would need a vision, Although in a volatile business environment, visions are generally evolved in shorter time horizon, it does not preclude one from envisioning the likely future in the next two decades.

Such long-term visions all within the realm of a futuristic forecast about the likely shape of banking. Such forecast goes beyond mere crystal gazing and fantasizing about the shape of things to come. All of us forecast constantly. Endowed with the great power of thinking, we are always thinking ahead, if not about anything else, at least about our personal futures. It is our nature to the future given our experiences, we also tend to think of the future and given our experiences, we tend to think about the past. Perhaps the toughest thing to do is to focus on the present. Leaving this aside in general the majority of us would like to think of the future. However, whatever shape of things we can visualize for the future, they are only possibilities, not certainties. Therefore, this fact should bear in mind when we talk of the Vision for 2030. Looking at such a long-term time horizon raises another metaphysical question. Is future already pre-determined as the popular saying goes "whatever will be, will be"? However, as rational human beings we also know that even if the future is predetermined, we are endowed with the power of changing it because future is also a subject of human choice. Thus while the future may not be fully predicted, yet it can very well be shaped through thoughtful choice.

Concept of Vision: A "Vision" is a mental articulation about the future state of things. It provides the energy and direction to an organization or a country. A powerful vision acts as a magnet and attracts people towards it. The visions were seen as future possibilities and thus were achieved. A more recent instance could be Bill Gates who envisioned about the future of computers and he could not only realize this vision but also become the richest man in USA in twenty years. Thus, a powerful and effective vision in itself contains the possibility of achievements.

Prospects of Global Scenario: Globalization means dependent on each other. On the same way, the globalization of the financial market can be cited as another. The increasing international flows, mainly initiated by large mutual funds, pension funds have been matched by the growing dispersion of domestic markets by foreign financial institutions. These institutions pay effect on the operational environment. The operational environment in the banking sector is totally changed. If we try to forecast the banking scenario two decades later, it would be useful to comprehend what will be the global scenario. It is very important because in the current globalizing world, dependent on each other. India is gradually integrating with the world economy and world is becoming more and more interdependent.

Vision over Global Trends in Indian Banking: In this backdrop, we try to visualize the global trends in the future and say about the next two decades.

- The digital society, networking, e-commerce virtual reality will continue to change consumer behavior and change economic, social, technology and political sphere.

- Major demographic and social shifts will occur and there will occur and there will be ageing, wealthy population. 
- Tribalism will be created through successful products and successful organizations.

- Emergence of global super-brand and huge pressures to manage global operations through new technologies, virtual teams etc.

- Global ethics will be powerful force and organizations will have to prove that they serve not only individuals but also provide for betterment of whole society.

\section{Literature Review}

Af-Tamini and Iabnoun. (2006) compares service quality and bank performance between national and foreign banks in the UAE. In addition, the paper compares the importance of the dimensions of the instrument between the two sets of the banks. The financial performance is compared using the of a Whitney nonparametric test. The results of this study will serve as a benchmark for UAE bankers from the 800 questionnaires, 480 responses were received. Kumar, (2006) studied the bank nationalization in India marked a paradigm shift in the focus of banking as it was intended to shift the focus from class banking to mass banking. Internationally also efforts are being made to study causes of financial inclusion and designing strategies to ensure financial inclusion of the poor disadvantaged. The banks also need to redesign their business strategies to incorporate specific plans to promote financial inclusion of low-income group treating it both a business opportunity as well as a corporate social responsibilities. Financial inclusion can emerge as commercial profitable business. Laxman, Deen, and Badiger, (2008) examined that banking industry is undergoing a paradigm shift in scope, content, structure, functions and governance. Their very characters, composition, contour and chemistry is changing. The information and communication technology revolution is radically and perceptibly changing the operational environment of the banks.

Lal, (2007) concludes that the main challenge ahead in the new millennium in banking and financial sector contain changing economic and banking environment, global competition, capital structure, transparency in reporting accounts, employee productivity, risk management, market discipline, sound human resource management, training and development. Muniappan, (2002) studied paradigm shift in banks from a regulator point of view. He concluded the positive effect of banking sector reforms on the performance of banks. He suggested many effective measures to strengthen the Indian banking system. The reduction of NPAs, more provisions for standards of the banks, IT, sound capital bare are the positive measures for a paradigm shift. A regulatory change is required in the Indian banking system. Madhavankutty, (2007) concludes the banking system in India has attained enough maturity and is ready to address prudential management practices as comprehensively as possible, which an integral part of policy is making. Banking in India is poised to enter yet another phase of reforms once the door opens further to foreign players in 2009. This requires further improvement in technology management, human resource management and the ability to foresee rapid changes in the financial landscape and adopt quickly. At present, there is a huge hiatus between the top management earnings of state owned banks and private, as well as foreign banks. Banks have to lay down sound risk management strategies and internal capital adequacy assessment committees to ensure that they do not diverge from the prudential requirements.

Nair, (2006) discusses the future challenges of technology in banking. The author also point out how IT posses a bright future in rural banking, but is neglected as it is traditionally considered unviable in the rural segment. A successful bank has to be nimble and agile enough to respond to the new market paradigm and ineffectively controlling risks. Innovation will be the key extending the banking services to the untapped vast potential at the bottom of the pyramid. Singla, (2008) examines that how financial management plays a crucial role industrialists growth of banking. It is concerned with examining the profitability position of the selected sixteen banks of banker index for a period of six years (2001-06). The study reveals that the profitability position was reasonable during the period of study when compared with the previous years. Strong capital position and balance sheet place. Banks in better position to deal with and absorb the economic constant over a period. Shroff, (2007) gives a summary of how Indian banking system has evolved over the year. The paper discusses some issues face by these systems. The author also gives examples of comparable banking system for other countries and the lesson learnt. Indian banking is at the threshold of the paradigm shift. The application of technology and product innovations is bringing about structure change in the Indian banking system. 
Subbaroo, (2007) concludes the Indian banking system has undergone transformation itself from domestic banking to international banking. However, the system requires a combination of new technologies, wellregulated risk and credit appraisal, treasury management, product diversification, internal control, external regulations and professional as well as skilled human resource to achieve the heights of the international excellence to play its role critically in meeting the global challenge. This paper mainly concentrates on the major trends that change the banking industry world over, viz. consolidation of players through mergers and acquisitions globalization of players, development of new technology, universal banking and human resource in banking, profitability, rural banking and risk management. Banks will have to gear up to meet stringent prudential capital adequacy norms under Basel I and II, the free trade agreements. Banks will also have to cope with challenges posed by technological innovations in banking Tiwari, (2005) proposed a view that among the financial intermediaries' banks and financial institutions are vital players in running the funding activities of the industries.

In the bank-based system, the financial institutions dominate taken together assets of the financial system while in market based system, equity market has largest share of assets taken together assets of the financial system. Uppal and Kaur, (2007) analysis the efficiency of all the bank groups in the post banking sector reforms era. Time of study is related to second post banking sector reforms (1999-2000 to 2004-05). The paper concludes that the efficiency of all the bank groups has increased in the second post banking sector reforms period but these banking sector reforms are more beneficial for new private sector banks and foreign banks. This paper also suggests some measures for the improvement of efficiency of Indian nationalized banks. The sample of the study in Indian banking industry that comprises five different ownership groups and the ratio method is used to calculate the efficiency of different bank groups. New private sector banks are compelling with foreign banks for continuous improvement in their performance.

\section{Methodology}

\section{Objective}

- To asses and analyze the changing face of Indian banking industry

- $\quad$ Predict the future for 2030

Data Base: In this study, the whole data is related with secondary data. The whole data is collected from the Report on Trend and Progress, RBI official publication, Mumbai and Information collected through IT Dept, IBA, and Mumbai.

Research Methodology: In this paper, we studied about the changing face of Indian banking in future. This paper is related with the different bank groups like public sector banks, old private sector banks, new private sector banks, foreign banks and banking industry.

Sample Plan: The present study is related to Indian banking industry. The banking industry is divided into four bank groups

G-1 Public Sector Banks

G-II Old Private Sector Banks

G-III New Private Sector Banks

G-IV Foreign Banks

Time: The data is collected for the period 1996-2007. The whole data is divided into two periods. Preebanking (1996-2001) period and post-ebanking period (2001-07).

Universe: This study is concerned with the Indian banking industry.

Parameters: To evaluate the changing scenario of the Indian banking industry through the following parameters.

- Business Per Employee( $\left.\mathrm{Y}_{0}\right)$

- Net Profit as Percentage of Working Funds( $\left(Y_{1}\right)$

- $\quad$ Computerized Branches as percentage of Total Branches( $\left(\mathrm{X}_{1}\right)$ 
- $\quad$ ATM Per Total Branches $\left(\mathrm{X}_{2}\right)$

- Credit Card Branches Per Total Branches $\left(\mathrm{X}_{3}\right)$

- Internet Banking Branches as Percentage of Total Branches( $\left(\mathrm{X}_{4}\right)$

- Mobile Banking Branches as Percentage of Total Branches( $\left(X_{5}\right)$

- Tele-Banking Branches as Percentage of Total Branches $\left(\mathrm{X}_{6}\right)$

- Indian banks operating in global market

- Foreign banks operating in India

- Performance of partially globalize and non-globalize banks

- Business and profit per employee of globalize and non-globalize NPSBs

- Average, S.D, C.V. and correlation coefficient is used to achieve the objective.

\section{Results and Interpretation}

Business per Employee: Business per employee is a potency of the banks, a combination of deposits and credits. Table 1 depict the similar picture where, G-III is at a glance with Rs.7.87 lakhs average follow by G-IV having Rs.5.88 lakhs average but comparatively industry with just Rs.1.24 lakhs average shows a poor performance in pre-ebanking period. During post-ebanking period, G-IV gain a lead by way of Rs.9.90 lakhs average against industry and partially IT-oriented banks minutes below Rs.4 lakhs average. It is imperative to note that fully IT-oriented banks prove greater average, lesser variations in distinction of partially IToriented banks and industry having poor performance due to higher variations along with other factors. Combined average also portrays the similar picture where fully IT-oriented banks are outlying the partially IT-oriented banks during the whole study period. The data is testimony for striking improvement (Rs.1 lakh to Rs.4 lakhs) in banks' concert in post-ebanking period over pre-ebanking period. The positive slit shows an incessant augmentation in banks' performance. G-IV accounts a noteworthy growth rate i.e. Rs.4.02 lakhs where industry demonstrates Rs.2.16 lakhs acceleration follow by G-II. Although, G-III is grow up by Rs.1.22 lakhs even record the highest average of Rs.8.53 lakhs with greater steadiness.

Table 1: Business per Employee Lakhs

\begin{tabular}{|c|c|c|c|c|c|c|}
\hline Period & Years & G-I & G-II & G-III & G-IV & Industry \\
\hline \multirow{8}{*}{$\begin{array}{l}\text { Pre } \\
\text { ebanking }\end{array}$} & 1996-97 & 0.76 & 1.01 & 7.70 & 4.51 & 0.85 \\
\hline & $1997-98$ & 0.86 & 1.16 & 6.50 & 4.54 & 0.96 \\
\hline & 1998-99 & 1.06 & 1.40 & 7.94 & 5.03 & 1.18 \\
\hline & $1999-2000$ & 1.25 & 1.70 & 9.76 & 6.31 & 1.41 \\
\hline & $2000-01$ & 1.60 & 2.00 & 7.46 & 9.03 & 1.80 \\
\hline & Average & 1.11 & 1.45 & 7.87 & 5.88 & 1.24 \\
\hline & S.D. & 0.33 & 0.40 & 1.19 & 1.90 & 0.38 \\
\hline & C.V. (\%) & 29.73 & 27.59 & 15.12 & 32.31 & 30.65 \\
\hline \multirow{9}{*}{$\begin{array}{l}\text { Post } \\
\text { ebanking }\end{array}$} & 2001-02 & 1.91 & 2.24 & 8.96 & 10.07 & 2.20 \\
\hline & $2002-03$ & 2.15 & 2.99 & 10.94 & 10.31 & 2.47 \\
\hline & 2003-04 & 2.47 & 3.17 & 8.73 & 9.57 & 2.87 \\
\hline & 2004-05 & 3.06 & 3.55 & 8.75 & 9.40 & 3.48 \\
\hline & 2005-06 & 3.69 & 4.23 & 9.02 & 10.08 & 4.24 \\
\hline & $2006-07$ & 4.61 & 4.96 & 8.11 & 9.95 & 5.15 \\
\hline & Average & 2.98 & 3.52 & 9.09 & 9.90 & 3.40 \\
\hline & S.D. & 1.03 & 0.96 & 0.96 & 0.34 & 1.13 \\
\hline & C.V. (\%) & 34.56 & 27.27 & 10.56 & 3.43 & 33.24 \\
\hline \multicolumn{2}{|c|}{ Combined Average } & 2.13 & 2.58 & 8.53 & 8.07 & 2.42 \\
\hline \multicolumn{2}{|c|}{ Avg. Productivity Gap } & 1.87 & 2.07 & 1.22 & 4.02 & 2.16 \\
\hline
\end{tabular}

Source: Same as in table 1

Entire data concludes that business per employee is the indication of remarkable expansion in post-ebanking period especially in partially IT-oriented banks, although fully IT-oriented banks are at a glance with greater average. 
Net Profits as Percentage of Working Funds: Net profit, a resulting difference of spread and burden, is an important tool to measure the financial efficiency and this ratio represents the share of assets occupied by net profits. It is seen from table 2 that G-III is at the top having $1.20 \mathrm{pc}$ averages in pre-ebanking period where industry is at lower level with 0.59 pc average. However, during post-ebanking period, G-IV takes a lead with $1.30 \mathrm{pc}$ average profitability and industry records $0.92 \mathrm{pc}$ average incompatible of G-II and I. It is important to note that G-II is at the lowest by means of $0.81 \mathrm{pc}$ average profitability mainly because of increase in burden. Combined average portrays different picture where fully IT-oriented banks have the highest average recording more than $1 \mathrm{pc}$ average profitability whereas partially IT-banks even industry proves below $1 \mathrm{pc}$ average. Positive average profitability gap is a testimony of improved performance in whole banking industry during post-ebanking period where G-IV is at the top by means of $0.59 \mathrm{pc}$ growth but G-III proves decline of $0.27 \mathrm{pc}$ due to higher decline in interest income still have good amount of average profitability. Although partially IT-oriented banks have improved their performance but record a notable gap from fully IT-oriented banks. Overall, it is concluded that post-ebanking period is a testimony of improved profitability with the utmost effect of IT along with other factors of transformation.

Table 2: Net Profits as Percentage of Working Funds Percent

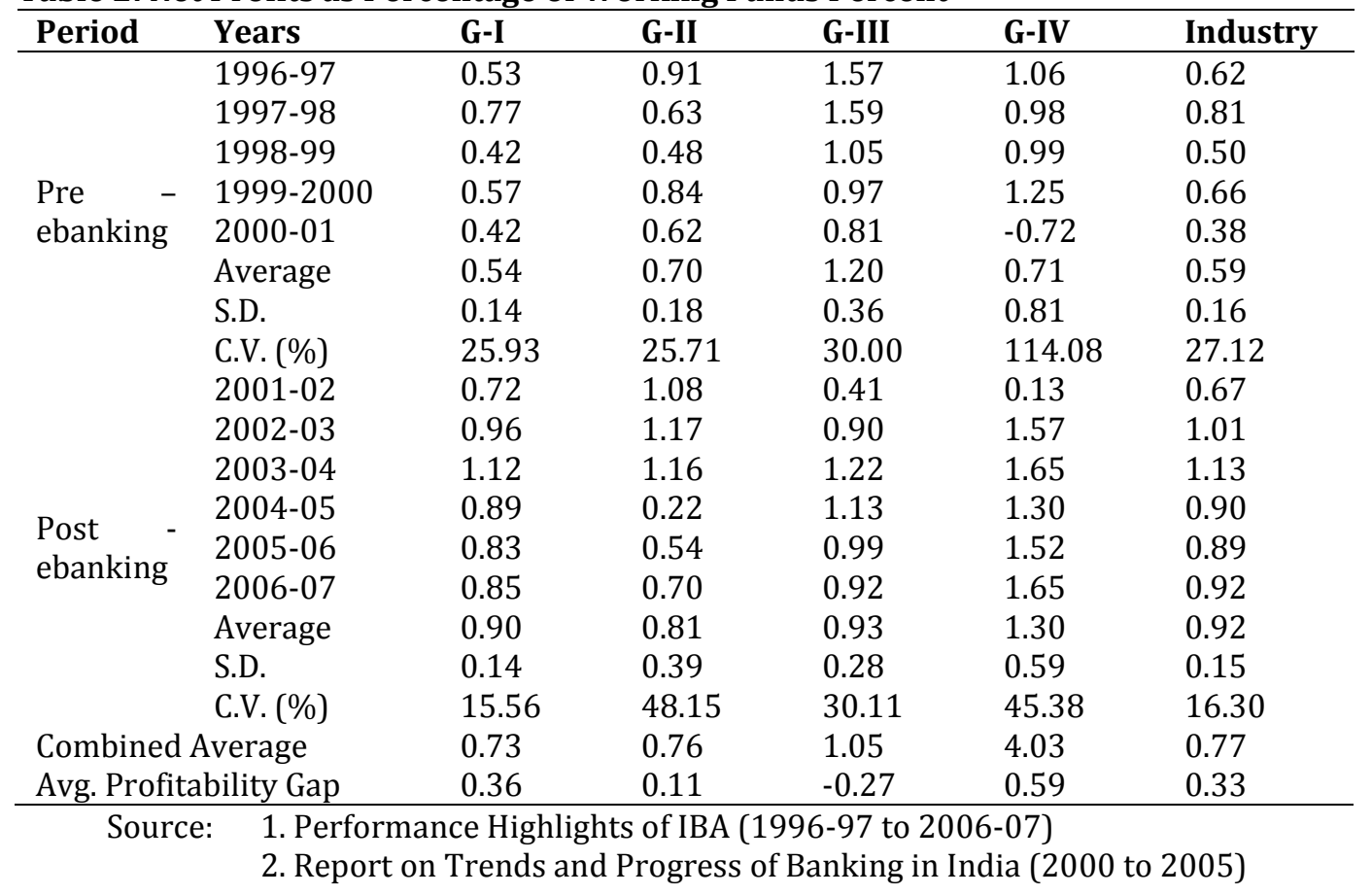

Computerized Branches as Percentage of Total Branches: Narasimahm Committee-II has recommended full computerization of the branches in 1998. Indian new private sector banks and foreign banks have entered in banking industry in 1996-97 with fully computerized system but public sector banks and old private sector banks are still in mounting stage. Table 3 depicts the analogous picture as fully IT-oriented banks are fully computerized from birth whereas partially IT-oriented banks have not computerized even $50 \mathrm{pc}$ of the total branches on an average in pre-ebanking period and hence industry also record just 57.88 pc branches computerized but gains $91.31 \mathrm{pc}$ average computerization during post-ebanking period. Partially IT-oriented banks also creep a look recording an admirable growth of nearly $50 \mathrm{pc}$ where G-I proves an explosive improvement i.e.57.68 pc from $24.82 \mathrm{pc}$ in pre-ebanking period to $82.50 \mathrm{pc}$ average in post-ebanking period. G-II and industry also witness excellent growth i.e. $47.36 \mathrm{pc}$ and $33.43 \mathrm{pc}$ respectively. Combined average also portrays a similar picture where industry has 76.11 pc averages during the whole study period. Postebanking period confirms remarkable speed of computerization of the branches but still partially IT-oriented banks are not harmonized with fully IT-oriented banks. This is also a major factor for superior productivity of these banks. 
Table 3: Computerized Branches as percentage of Total Branches Percent

\begin{tabular}{|c|c|c|c|c|c|c|}
\hline Period & Years & G-I & G-II & G-III & G-IV & Industry \\
\hline \multirow{8}{*}{$\begin{array}{l}\text { Pre - } \\
\text { ebanking }\end{array}$} & 1996-97 & 0.11 & 0.02 & 100.00 & 100.00 & 49.80 \\
\hline & $1997-98$ & 1.82 & 1.79 & 100.00 & 100.00 & 50.00 \\
\hline & 1998-99 & 34.94 & 8.88 & 100.00 & 100.00 & 51.15 \\
\hline & $1999-2000$ & 38.31 & 13.94 & 100.00 & 100.00 & 60.55 \\
\hline & $2000-01$ & 48.90 & 19.69 & 100.00 & 100.00 & 77.91 \\
\hline & Average & 24.82 & 8.86 & 100.00 & 100.00 & 57.88 \\
\hline & S.D. & 22.38 & 8.23 & 0.00 & 0.00 & 12.05 \\
\hline & C.V. (\%) & 90.17 & 92.89 & 0.00 & 0.00 & 2.08 \\
\hline \multirow{9}{*}{$\begin{array}{l}\text { Post - } \\
\text { ebanking }\end{array}$} & 2001-02 & 61.36 & 23.16 & 100.00 & 100.00 & 89.05 \\
\hline & 2002-03 & 72.71 & 46.32 & 100.00 & 100.00 & 91.28 \\
\hline & 2003-04 & 79.67 & 48.60 & 100.00 & 100.00 & 90.67 \\
\hline & 2004-05 & 88.87 & 67.22 & 100.00 & 100.00 & 90.62 \\
\hline & $2005-06$ & 94.39 & 71.10 & 100.00 & 100.00 & 90.31 \\
\hline & $2006-07$ & 98.02 & 80.94 & 100.00 & 100.00 & 95.91 \\
\hline & Average & 82.50 & 56.22 & 100.00 & 100.00 & 91.31 \\
\hline & S.D. & 13.95 & 20.99 & 0.00 & 0.00 & 2.37 \\
\hline & C.V. (\%) & 16.91 & 37.33 & 0.00 & 0.00 & 2.60 \\
\hline \multirow{2}{*}{\multicolumn{2}{|c|}{$\begin{array}{l}\text { Combined Average } \\
\text { Avg. Technology Gap }\end{array}$}} & 56.28 & 34.70 & 100.00 & 100.00 & 76.11 \\
\hline & & 57.68 & 47.36 & 0.00 & 0.00 & 33.43 \\
\hline
\end{tabular}

Source: Information collected through IT Dept., IBA Mumbai

ATMs per Total Branches: ATMs are the most compassionate and speedy tool of IT for banking transactions especially for cash withdrawal and mini statement of account. Table 4 shows that only fully IT-oriented banks have installed ATMs in 1996-97 but G-I in 1997-98 and G-II in 1999-2000. Pre-ebanking period show up the average where G-IV fleet a look with 0.96 average ATMs per branch follow by G-III but industry has just negligible average means not even a single ATM for single branch.

Table 4: ATMs per Total Branches

\begin{tabular}{|c|c|c|c|c|c|c|}
\hline Period & Years & G-I & G-II & G-III & G-IV & Industry \\
\hline \multirow{8}{*}{$\begin{array}{l}\text { Pre - } \\
\text { ebanking }\end{array}$} & 1996-97 & 0.00 & 0.00 & 0.20 & 0.85 & 0.02 \\
\hline & 1997-98 & 0.02 & 0.00 & 0.39 & 0.79 & 0.05 \\
\hline & 1998-99 & 0.09 & 0.00 & 0.86 & 0.84 & 0.05 \\
\hline & $1999-2000$ & 0.12 & 0.01 & 0.64 & 0.99 & 0.05 \\
\hline & $2000-01$ & 0.14 & 0.12 & 0.41 & 1.33 & 0.06 \\
\hline & Average & 0.07 & 0.03 & 0.50 & 0.96 & 0.05 \\
\hline & S.D. & 0.06 & 0.05 & 0.25 & 0.22 & 0.02 \\
\hline & C.V. (\%) & 85.71 & 166.67 & 50.00 & 22.92 & 40.00 \\
\hline \multirow{9}{*}{$\begin{array}{l}\text { Post - } \\
\text { ebanking }\end{array}$} & 2001-02 & 0.17 & 0.16 & 0.43 & 1.31 & 0.06 \\
\hline & $2002-03$ & 0.19 & 0.22 & 0.59 & 2.17 & 0.09 \\
\hline & 2003-04 & 0.20 & 0.23 & 0.52 & 1.89 & 0.09 \\
\hline & 2004-05 & 0.21 & 0.27 & 0.82 & 2.94 & 0.17 \\
\hline & $2005-06$ & 0.25 & 0.62 & 0.89 & 1.70 & 0.16 \\
\hline & 2006-07 & 0.34 & 0.86 & 1.76 & 2.34 & 0.34 \\
\hline & Average & 0.23 & 0.39 & 0.84 & 2.06 & 0.15 \\
\hline & S.D. & 0.06 & 0.28 & 0.49 & 0.56 & 0.10 \\
\hline & C.V. (\%) & 26.09 & 71.79 & 58.33 & 27.18 & 6.67 \\
\hline \multirow{2}{*}{\multicolumn{2}{|c|}{$\begin{array}{l}\text { Combined Average } \\
\text { Avg. Technology Gap }\end{array}$}} & 0.16 & 0.23 & 0.68 & 1.56 & 0.10 \\
\hline & & 0.16 & 0.36 & 0.34 & 1.10 & 0.10 \\
\hline
\end{tabular}

Source: Information collected through IT Dept., IBA Mumbai

Post-ebanking period, with greater variations highlights that completely banking industry has gained excellent improvement in ATMs' installation, where G-IV again takes a lead having average 2 ATMs per branch and record admirable growth. Comparatively other bank group's even industry has not installed 
single ATM per branch on an average although G-III perks up and confirms better record. Combined average establishes similar position. Partially IT-oriented banks are still not harmonized with fully IT-oriented banks that are why their performance is comparatively poor. Hence, post-ebanking period confirms remarkable performance due to much effect of IT in terms of different channels as ATMs is one of these channels.

Credit Cards per Total Branches: Credit cards, an excellent version of IT for banking and shopping in market, has gained momentum share among all IT channels. Table 5 shows that during pre-ebanking period, G-IV is the most admired one for credit cards, evidence from its highest average (nearly 1842 cards per branch) whereas industry records average 16 cards per branch only because partially IT-oriented banks have not even 10 cards per branch an awkward figure. It is the depiction in post-ebanking period where also G-IV takes a lead by means about 4008 average credit cards per branch. Partially IT-oriented banks and industry trace much lesser average just 14 to 36 cards per branch. Combined average also depicts similar picture. Concerns that stability is more in post-ebanking period consequences improved state of affairs.

Table 5: Credit Cards per Total Branches

\begin{tabular}{|c|c|c|c|c|c|c|}
\hline Period & Years & G-I & G-II & G-III & G-IV & Industry \\
\hline \multirow{8}{*}{$\begin{array}{l}\text { Pre } \\
\text { ebanking }\end{array}$} & 1996-97 & 0.02 & 0.00 & 405.21 & 576.01 & 10.49 \\
\hline & $1997-98$ & 4.88 & 0.00 & 682.05 & 1172.28 & 15.40 \\
\hline & 1998-99 & 13.98 & 0.46 & 846.36 & 1713.16 & 17.31 \\
\hline & $1999-2000$ & 14.52 & 0.86 & 675.18 & 2381.28 & 17.96 \\
\hline & 2000-01 & 16.00 & 4.96 & 412.69 & 3365.01 & 20.91 \\
\hline & Average & 9.88 & 1.26 & 604.30 & 1841.55 & 16.41 \\
\hline & S.D. & 7.04 & 2.10 & 191.06 & 1081.46 & 3.86 \\
\hline & C.V. (\%) & 71.25 & 166.67 & 31.62 & 58.73 & 23.52 \\
\hline \multirow{9}{*}{$\begin{array}{l}\text { Post - } \\
\text { ebanking }\end{array}$} & 2001-02 & 16.62 & 6.97 & 432.38 & 3340.21 & 22.49 \\
\hline & 2002-03 & 16.95 & 12.54 & 542.95 & 3730.65 & 32.04 \\
\hline & 2003-04 & 18.11 & 11.82 & 506.28 & 3322.63 & 36.21 \\
\hline & 2004-05 & 19.24 & 14.79 & 413.20 & 6110.05 & 36.02 \\
\hline & 2005-06 & 20.47 & 16.27 & 399.54 & 3729.19 & 35.42 \\
\hline & 2006-07 & 38.95 & 21.69 & 483.26 & 3813.83 & 53.99 \\
\hline & Average & 21.72 & 14.01 & 462.94 & 4007.76 & 36.03 \\
\hline & S.D. & 8.56 & 4.92 & 56.78 & 1051.35 & 10.22 \\
\hline & C.V. (\%) & 39.41 & 35.12 & 12.27 & 26.23 & 28.37 \\
\hline \multirow{2}{*}{\multicolumn{2}{|c|}{$\begin{array}{l}\text { Combined Average } \\
\text { Avg. Technology Gap }\end{array}$}} & 16.34 & 8.21 & 527.19 & 3023.12 & 27.11 \\
\hline & & 11.84 & 12.75 & -141.36 & 2166.21 & 19.62 \\
\hline
\end{tabular}

Source: Information collected through IT Dept., IBA Mumbai

Post-ebanking period confirms excellent growth in credit cards' strength especially in G-IV (2166) whereas other bank groups and industry reports not even 20 cards per branch. G-III takes attention by recording average fall of 141.36 cards per branch mainly because of greater plunge during $2004-2006$ and secondly due to the entrance of two new banks (Yes Bank and Kotak Mohindra Bank). Even though post-ebanking period confirms an improved strength of credit cards but still partially IT-oriented banks are not harmonized with fully IT-oriented banks more particularly G-IV, reporting gap in thousands.

Internet Banking Branches as Percentage of Total Branches: Today's internet banking is also a much popular approach of banking. This ratio represents an extent of branches providing internet-banking services. Table 6 demonstrates that G-III fleet a look with 36.64 pc average and industry records just $3.31 \mathrm{pc}$ averages, 12 times lesser in pre-ebanking period bearing numerous variations. During post-ebanking period also, bank groups perk up average largely where G-III with $74.68 \mathrm{pc}$ average takes an attention moreover industry records just $14.87 \mathrm{pc}$ average in compatible of G-II \& I. Combined average proves that partially IToriented banks accounts a larger distance from fully IT-oriented banks nearly 6 to 7 times that are noteworthy. Constructive gap confirms an impressive growth in internet banking all through post-ebanking period where G-III tops with 38.04 pc expansion and G-IV follows. Overall, it is concluded that post-ebanking period is steadier since more average of internet banking and more is the stability as is evidence from the records. It has pitched a banking business to the commanding heights. 
Table 6: Internet Banking Branches as percentage of Total Branches Percent

\begin{tabular}{lllllll}
\hline Period & Years & G-I & G-II & G-III & G-IV & Industry \\
\hline \multirow{5}{*}{ Pre } & $1996-97$ & 0.00 & 0.00 & 5.75 & 8.79 & 1.25 \\
ebanking & $1997-98$ & 1.11 & 0.00 & 13.11 & 16.67 & 2.60 \\
& $1998-99$ & 1.82 & 0.00 & 43.48 & 25.57 & 3.34 \\
& $1999-2000$ & 3.04 & 3.91 & 46.71 & 31.49 & 4.10 \\
& $2000-01$ & 4.57 & 6.26 & 74.16 & 42.14 & 5.26 \\
& Average & 2.11 & 2.03 & 36.64 & 24.93 & 3.31 \\
& S.D. & 1.76 & 2.91 & 27.68 & 12.93 & 1.51 \\
Post & C.V. (\%) & 83.41 & 143.35 & 75.55 & 51.87 & 45.62 \\
ebanking & 2001-02 & 6.14 & 7.98 & 72.98 & 45.58 & 7.58 \\
& 2002-03 & 8.68 & 15.06 & 80.81 & 47.22 & 8.59 \\
& 2003-04 & 12.40 & 15.61 & 77.90 & 41.94 & 9.82 \\
& 2004-05 & 13.69 & 17.68 & 62.88 & 78.01 & 12.37 \\
& 2006-07 & 16.29 & 20.72 & 74.23 & 47.37 & 14.81 \\
Average & 23.64 & 24.98 & 79.25 & 56.54 & 36.07 \\
Avg. Technology Gap & 13.47 & 17.00 & 74.68 & 52.78 & 14.87 \\
& S.D. & 6.15 & 5.75 & 6.50 & 13.27 & 10.71 \\
& C.V. (\%) & 45.66 & 33.82 & 8.70 & 25.14 & 72.02 \\
\hline
\end{tabular}

Source: Information collected through IT Dept., IBA Mumbai

Mobile Banking Branches as Percentage of Total Branches: Mobile-banking is also trendy even prior to the internet-banking which is mainly availed for balance checking, billing and other account related instructions to the banks. Table 7 highlights the major findings where G-III steals a look with 31.85 pc average comparatively G-I \& II and industry view just 2 pc averages during pre-ebanking period.

Table 7: Mobile Banking Branches as percentage of Total Branches Percent

\begin{tabular}{|c|c|c|c|c|c|c|}
\hline Period & Years & G-I & G-II & G-III & G-IV & Industry \\
\hline & 1996-97 & 0.21 & 0.00 & 4.99 & 9.81 & 0.99 \\
\hline & $1997-98$ & 0.64 & 0.00 & 8.20 & 13.89 & 1.60 \\
\hline & 1998-99 & 1.37 & 0.00 & 34.78 & 20.45 & 1.87 \\
\hline Pre & $1999-2000$ & 2.31 & 2.28 & 46.71 & 22.65 & 1.96 \\
\hline \multirow[t]{7}{*}{ ebanking } & $2000-01$ & 3.49 & 6.92 & 64.59 & 40.71 & 3.68 \\
\hline & Average & 1.60 & 1.84 & 31.85 & 21.50 & 2.02 \\
\hline & S.D. & 1.32 & 3.01 & 25.41 & 11.90 & 1.00 \\
\hline & C.V. (\%) & 82.50 & 163.59 & 79.78 & 55.35 & 49.50 \\
\hline & 2001-02 & 4.14 & 7.17 & 69.64 & 40.14 & 3.88 \\
\hline & $2002-03$ & 5.48 & 12.56 & 72.73 & 45.00 & 5.54 \\
\hline & 2003-04 & 7.68 & 13.57 & 71.21 & 44.24 & 7.16 \\
\hline \multirow{6}{*}{$\begin{array}{l}\text { Post - } \\
\text { ebanking }\end{array}$} & 2004-05 & 11.52 & 13.45 & 56.60 & 75.89 & 8.49 \\
\hline & $2005-06$ & 15.84 & 17.80 & 69.26 & 46.96 & 11.20 \\
\hline & $2006-07$ & 24.91 & 24.94 & 82.32 & 57.31 & 25.46 \\
\hline & Average & 11.60 & 14.92 & 70.29 & 51.59 & 10.29 \\
\hline & S.D. & 7.79 & 5.97 & 8.25 & 13.22 & 7.84 \\
\hline & C.V. (\%) & 67.16 & 40.01 & 11.74 & 25.63 & 76.19 \\
\hline \multicolumn{2}{|c|}{ Combined Average } & 7.05 & 8.97 & 52.82 & 37.91 & 6.53 \\
\hline \multicolumn{2}{|c|}{ Avg. Technology Gap } & 10.00 & 13.08 & 38.44 & 30.09 & 8.27 \\
\hline
\end{tabular}

Source: Information collected through IT Dept., IBA Mumbai

Post-ebanking period shows improvement incase of all banks groups where G-III again takes a lead with 70.29 pc average about 5 to 7 times more than G-II, industry and I. Combined average also foresees an explosive gap between partially IT-oriented and fully IT-oriented banks that cannot be ignored. Gap between pre and post ebanking period signifies growth in mobile banking services in post-ebanking period, where also 
fully IT-oriented banks capture a look reporting more than 30 pc growth but partially IT-oriented banks demonstrate not even 15 pc growths. Rather partially IT-oriented banks are far behind by way of 5 to 7 times lesser average mainly due to greater variations along with other factors. Generally, it is concluded that postebanking period is steadier with the utmost effect on G-III. This is due to encouraging contribution of IT, the most productive stick of competition. IT.

Tele-Banking Branches as Percentage of Total Branches: Tele-banking encourages banking on telephones for limited operations. Table 8 represents comparative view where average share of tele-banking branches of total

Table 8: Tele-Banking Branches as percentage of Total Branches Percent

\begin{tabular}{lllllll}
\hline Period & Years & G-I & G-II & G-III & G-IV & Industry \\
\hline \multirow{5}{*}{ Pre } & $1996-97$ & 0.01 & 0.00 & 5.77 & 10.71 & 0.97 \\
ebanking & $1997-98$ & 0.33 & 0.00 & 9.18 & 16.67 & 1.62 \\
& $1998-99$ & 0.63 & 0.00 & 23.19 & 27.27 & 1.77 \\
& $1999-2000$ & 1.26 & 2.78 & 42.89 & 28.18 & 1.85 \\
& $2000-01$ & 1.75 & 5.74 & 38.28 & 42.14 & 2.14 \\
& Average & 0.80 & 1.70 & 23.86 & 24.99 & 1.67 \\
& S.D. & 0.70 & 2.56 & 16.68 & 12.07 & 0.43 \\
& C.V. (\%) & 87.50 & 150.59 & 69.91 & 48.30 & 25.75 \\
& 2001-02 & 2.27 & 8.84 & 46.26 & 45.58 & 3.29 \\
& 2002-03 & 4.05 & 10.91 & 65.86 & 43.89 & 3.63 \\
Post & 2003-04 & 5.28 & 11.44 & 57.58 & 40.09 & 5.48 \\
ebanking & 2004-05 & 6.29 & 13.32 & 49.75 & 63.83 & 7.41 \\
& 2005-06 & 8.24 & 18.48 & 41.92 & 44.53 & 10.31 \\
& 2006-07 & 16.50 & 22.84 & 47.93 & 58.46 & 22.93 \\
& Average & 7.11 & 14.31 & 51.55 & 49.40 & 8.84 \\
& S.D. & 5.03 & 5.31 & 8.70 & 9.44 & 7.38 \\
Combined Average & 4.24 & 8.58 & 38.96 & 38.30 & 5.58 \\
Avg. Technology Gap & 6.31 & 12.61 & 27.69 & 24.41 & 7.17 \\
\hline \multicolumn{5}{r}{ Souras }
\end{tabular}

Source: Information collected through IT Dept., IBA Mumbai

branches is more in fully IT-oriented banks in pre-ebanking period and industry do not show even 2 pc average having large variations. Comparatively, post-ebanking period proves slight upgrading where again GIII is at a peek (51.55 pc). Combined average also demonstrates almost $30 \mathrm{pc}$ lesser average of partially IToriented banks even industry reports just about 6 pc average an alarming gap of nearly 10 times. Postebanking period confirms striking improvement in tale-banking services in all bank groups but G-III take an attention as grew by $27.69 \mathrm{pc}$ and industry with just $7.17 \mathrm{pc}$ growth is far behind. The facts describe that partially IT-oriented banks, although prove 6 to 13 pc growth, still not harmonized with fully IT-oriented banks and a major factor is IT, a vigor of these banks but a weak point for others. Overall conclusion drawn from data is that post-ebanking period is an indication of remarkable improvement in tele-banking business in fully IT-oriented banks whereas partially IT-oriented banks, even having much lesser average. All bank groups show more stabling in post-ebanking period but industry proves higher competition witness by increased variations.

Indian Banks Operating In Global Market: Table 9 listed the public sector and new private sector banks working at abroad. It is crystal clear from the table that even after the sixteen years of the enactment of the LPG policy, Indian banking industry is far away from achieving $100 \mathrm{pc}$ globalization of its banks. Indian banking industry has 28 public sector banks, but only 13 banks out of it have branches, subsidiaries, representative offices and joint venture banks working in some foreign countries. The present share of public sector banks at abroad is $87 \mathrm{pc}$ and that of new private sector banks is only $13 \mathrm{pc}$. Out of public sector banks, Bank of Baroda had the largest share (29 pc) in 2006-07, followed by State Bank of India (26 pc) \& Bank of India (14.50). These banks have 56, 50 and 28 branches respectively working in some foreign countries. The maximum branches of these banks are working in Indonesia, China, Canada and UK. Similarly, among new 
private sector banks, ICICI Bank had the largest share ( $8.81 \mathrm{pc}$ ); it has 17 branches working at abroad. Although, these numbers of branches are not sufficient to give Indian banking industry the shield of globalized Indian banking industry but increase in number of branches to 21 in one year indicates the success story of Indian banks in cross border business.

Table 9: List of Indian Banks Operating in Global Market

\begin{tabular}{|c|c|c|c|c|}
\hline \multirow[t]{2}{*}{ Name of Bank } & \multicolumn{2}{|c|}{ Total Branches } & \multicolumn{2}{|c|}{$\begin{array}{l}\text { \%age Share in global } \\
\text { Market }\end{array}$} \\
\hline & 2005-06 & 2006-07 & 2005-06 & 2006-07 \\
\hline Public Sector Banks & 151 & 168 & 87.79 & 87.05 \\
\hline 1. Allahabad Bank & 1 & 2 & 0.58 & 1.03 \\
\hline 2. Andhra Bank & 1 & 1 & 0.58 & 0.52 \\
\hline 3. Bank of Baroda & 51 & 56 & 29.65 & 29.00 \\
\hline 4. Bank of India & 26 & 28 & 15.12 & 14.50 \\
\hline 5. Bharat Overseas Bank & 1 & N.A & 0.58 & - \\
\hline 6. Canara Bank & 3 & 4 & 1.74 & 2.07 \\
\hline 7. Indian Bank & 3 & 3 & 1.74 & 1.55 \\
\hline 8. Indian Overseas Bank & 8 & 9 & 4.65 & 4.66 \\
\hline 9. Punjab National Bank & 6 & 7 & 3.49 & 3.63 \\
\hline 10. State Bank of India & 45 & 50 & 26.16 & 25.91 \\
\hline 11. Syndicate Bank & 1 & 1 & 0.58 & 0.52 \\
\hline 12. UCO Bank & 5 & 6 & 2.91 & 3.11 \\
\hline 13. Union Bank & N.A & 1 & - & 0.52 \\
\hline New Private Sector Banks & 21 & 25 & 12.21 & 12.95 \\
\hline 14. Axis Bank & 1 & 4 & 0.58 & 2.07 \\
\hline 15. Centurian Bank of Punjab Ltd. & 2 & 1 & 1.16 & 0.52 \\
\hline 16. HDFC Bank Ltd. & 1 & 1 & 0.58 & 0.52 \\
\hline 17. ICICI Bank Ltd. & 15 & 17 & 8.72 & 8.81 \\
\hline 18. Industrial Bank Ltd. & 2 & 2 & 1.16 & 1.04 \\
\hline Total & 172 & 193 & - & - \\
\hline
\end{tabular}

Source: Report on Trend and Progress of Banking in India, RBI, 2006-07, pp. 110-111.

Note: N.A- Not Available

Foreign Banks Operating In India: Table 10 listed the foreign banks branches operating in Indian market. Indian market has 273 foreign banks of different countries. Out of these foreign banks, Standard Charted Bank of UK has the largest share, i.e. 30.40 pc. It has 83 branches working in India. After that comes the number of HSBC Bank of Hong Kong. It has 47 branches followed by Citibank of USA (39) and ABN- AMRO Bank of Nethersland (28).

Table 10: List of Foreign Banks Operating in India - Country Wise (As at end- October 2007)

\begin{tabular}{lllll}
\hline $\begin{array}{l}\text { S. } \\
\text { No. }\end{array}$ & Name of Bank & $\begin{array}{l}\text { Country } \\
\text { Incorporation }\end{array}$ & $\begin{array}{c}\text { of } \\
\begin{array}{l}\text { No. } \\
\text { branches } \\
\text { in India }\end{array}\end{array}$ & $\begin{array}{l}\text { \%age } \\
\text { Share }\end{array}$ \\
\hline 1. & ABN-AMRO Bank N.V. & Netherlands & 28 & 10.26 \\
2. & Abu Dhabi Commercial Bank Ltd. & UAE & 2 & 0.73 \\
3. & Arab Bangladesh Bank Ltd. & Bangladesh & 1 & 0.37 \\
4. & American Express Bank Ltd. & USA & 7 & 2.56 \\
5. & Antwerp Diamond Bank N.V. & Belgium & 1 & 0.37 \\
6. & Bank International Indonesia & Indonesia & 1 & 0.37 \\
7. & Bank of America & USA & 5 & 1.83 \\
8. & Bank of Bahrain \& Kuwait BSC & Bahrain & 2 & 0.73 \\
9. & Bank of Nova Scotia & Canada & 5 & 1.83 \\
10. & Bank of Tokyo-Mitsubishi UFJ Ltd. & Japan & 3 & 1.09 \\
11. & BNP Paribas & France & 8 & 2.93 \\
12. & Bank of Ceylon & Sri Lanka & 1 & 0.37
\end{tabular}




\begin{tabular}{lllll} 
13. & Barclays Bank Plc & UK & 4 & 1.47 \\
14. & Calyon Bank & France & 5 & 1.83 \\
15. & Citibank N.A. & USA & 39 & 14.29 \\
16. & Chinatrust Commercial Bank & Taiwan & 1 & 0.37 \\
17. & Deutsche Bank & Germany & 11 & 4.03 \\
18. & DBS Bank Ltd. & Singapore & 2 & 0.73 \\
19. & HSBC & Hongkong & 47 & 17.22 \\
20. & J.P. Morgan Chase Bank N.A. & USA & 1 & 0.37 \\
21. & Krung Thai Bank Public Co. Ltd. & Thailand & 1 & 0.37 \\
22. & Mizuho Corporate Bank Ltd. & Japan & 2 & 0.73 \\
23. & Mahreqbank PSC & UAE & 2 & 0.73 \\
24. & Oman International Bank SAOG & Sultanate of Omen & 2 & 0.73 \\
25. & Shinhan Bank & South Korea & 2 & 0.73 \\
26. & Standard Charted Bank & UK & 83 & 30.40 \\
27. & Sonali Bank & Bangladesh & 2 & 0.73 \\
28. & Societe Generale & France & 2 & 0.73 \\
29. & State Bank of Mauritius & Mauritius & 3 & 1.09 \\
& Total & & 273 & - \\
\hline
\end{tabular}

Source: Same as table 9

These banks have respectively 17.22 pc, 14.29 pc \& 10.26 pc share in Indian market. Other countries like Canada, France, Sri Lanka, etc. have also bank branches in the Indian market but their respective shares are comparatively low.

Performance of Partially Globalized and Non- Globalized Banks: Citrus paribus, comparative study of the performance of globalized banks with that of non-globalized banks will give the clear picture about globalization that weather it is positively affecting the Indian banking industry or hitting hard to it.

Business \& Profit per Employee of Globalized and Non-Globalized PSBs: As is evident from table 11, among globalised PSBs, business per employee of Bharat Overseas Bank is highest i.e. 370.40. After that, comes the number of Canara Bank, followed by Union Bank, Andhra Bank and Bank of Baroda. BUS/E of these banks is $350.67,339.95,334.85 \& 329.99$ respectively. All other globalized public sector banks have BUS/E greater than 200 and less than 300. Although BUS/E of some globalized public sector banks is less than that of non-globalized banks but the average of BUS/E of globalized banks is greater. Similarly, profit/E of some globalized public sector banks is less than that of non-globalized banks but the average is high in case of globalized banks.

Out of 13 banks, 9 banks have very high, positive and significant correlation between business per employee and Profit per employee. However, Bharat Overseas Bank that has some branches at abroad has negative correlation. On the other hand, some banks (State Bank of Bikaner \& Jaipur, State Bank of Indore \& State Bank of Saurashta) have no branch in the global market have negative correlation between business per employee and Profit per employee. Some banks have positive but very low correlation. Only Punjab \& Sind Bank, State Bank of Hyderabad, State Bank of Mysore and State Bank of Travancore have high, positive, and even significant correlation. 
Table 11: Business \& Profit per Employee of Partially Globalized and Non-Globalized PSBs

\begin{tabular}{|c|c|c|c|c|c|c|c|}
\hline \multirow{2}{*}{$\begin{array}{l}\text { Name of Bank } \\
\text { Globalized PSBs }\end{array}$} & \multicolumn{3}{|c|}{ Business/Employee } & \multicolumn{3}{|c|}{ Profit/Employee } & \multirow[t]{2}{*}{$\mathbf{r}$} \\
\hline & Mean & SD & $\mathrm{CV}$ & Mean & SD & $\mathrm{CV}$ & \\
\hline 1. Allahabad Bank & 270.83 & 112.58 & 41.57 & 2.38 & 1.46 & 61.34 & $0.907^{*}$ \\
\hline 2. Andhra Bank & 334.85 & 129.11 & 38.56 & 3.34 & 0.93 & 27.84 & $0.762^{*}$ \\
\hline 3. Bank of Baroda & 329.99 & 127.44 & 38.62 & 2.05 & 0.48 & 23.41 & 0.699 \\
\hline 4. Bank of India & 321.24 & 104.33 & 32.48 & 1.78 & 0.72 & 40.45 & 0.469 \\
\hline 5. Bharat Overseas Bank & 370.40 & 87.79 & 23.70 & 2.14 & 1.09 & 50.93 & -0.620 \\
\hline 6. Canara Bank & 350.67 & 125.59 & 35.81 & 2.60 & 0.59 & 22.69 & $0.828^{*}$ \\
\hline 7. Indian Bank & 237.33 & 80.51 & 29.46 & 1.79 & 1.21 & 67.59 & $0.940^{* *}$ \\
\hline 8. Indian Overseas Bank & 283.95 & 109.15 & 38.44 & 2.44 & 1.11 & 45.49 & $0.967^{* *}$ \\
\hline 9. Punjab National Bank & 267.80 & 89.82 & 33.54 & 1.98 & 0.67 & 33.84 & $0.919 * *$ \\
\hline 10. State Bank of India & 245.65 & 70.39 & 28.65 & 1.84 & 0.46 & 25.0 & $0.918^{* *}$ \\
\hline 11. Syndicate Bank & 282.24 & 122.97 & 43.57 & 1.69 & 0.65 & 38.46 & $0.980^{* *}$ \\
\hline 12. UCO Bank & 296.83 & 115.61 & 38.95 & 1.14 & 0.44 & 38.59 & 0.266 \\
\hline 13. Union Bank & 339.95 & 113.71 & 33.45 & 2.48 & 0.71 & 28.63 & $0.793^{*}$ \\
\hline Non-Globalized PSBs & & & & & & & \\
\hline 14. Bank of Maharashtra & 281.30 & 74.62 & 26.53 & 1.39 & 0.66 & 47.48 & 0.220 \\
\hline 15. Central Bank of India & 208.22 & 56.68 & 27.22 & 0.95 & 0.44 & 46.32 & 0.423 \\
\hline 16. Corporation Bank & 431.09 & 131.32 & 30.46 & 4.15 & 0.70 & 16.87 & 0.531 \\
\hline 17. Dena Bank & 312.00 & 87.92 & 28.18 & 1.12 & 0.83 & 74.11 & 0.434 \\
\hline $\begin{array}{l}\text { 18. Oriental Bank of } \\
\text { Commerce }\end{array}$ & 483.69 & 159.49 & 32.97 & 4.76 & 1.57 & 32.98 & 0.710 \\
\hline 19. Punjab \& Sind Bank & 234.43 & 56.69 & 24.18 & 0.52 & 1.07 & 205.77 & $0.870^{*}$ \\
\hline 20. United Bank of India & 214.50 & 77.15 & 35.97 & 1.45 & 0.44 & 30.34 & 0.183 \\
\hline 21. Vijaya Bank & 291.22 & 109.05 & 37.45 & 2.38 & 1.16 & 48.74 & 0.294 \\
\hline $\begin{array}{l}\text { 22. State Bank of Bikaner } \\
\text { \& Jaipur }\end{array}$ & 218.35 & 90.99 & 41.67 & 2.32 & 1.64 & 70.69 & -0.060 \\
\hline $\begin{array}{l}\text { 23. State Bank of } \\
\text { Hyderabad }\end{array}$ & 314.30 & 116.73 & 37.14 & 2.65 & 0.86 & 32.45 & $0.824^{*}$ \\
\hline 24. State Bank of Indore & 303.69 & 122.99 & 40.49 & 2.58 & 0.64 & 24.81 & -0.035 \\
\hline 25. State Bank of Mysore & 220.96 & 104.45 & 47.27 & 1.78 & 0.72 & 40.45 & $0.843^{*}$ \\
\hline 26. State Bank of Patiala & 366.60 & 153.74 & 41.94 & 2.80 & 0.59 & 21.07 & 0.390 \\
\hline $\begin{array}{l}\text { 27.State Bank of } \\
\text { Saurashtra }\end{array}$ & 237.19 & 77.85 & 32.82 & 1.19 & 0.66 & 55.46 & -0.392 \\
\hline $\begin{array}{l}\text { 28. State Bank of } \\
\text { Travancore }\end{array}$ & 316.97 & 119.80 & 37.79 & 2.04 & 0.67 & 32.84 & $0.954^{* *}$ \\
\hline
\end{tabular}

Source: Report on Trend and Progress of Banking in India 2006-07, pp.316-317. A Profile of Banks, 2005-06

Business \& Profit Per Employee Of Globalized And Non-Globalized NPSBs; It is clear from table 12 that BUS/E of new private sector banks is higher than that of Non-globalized banks which indicated the fact that globalization has its positive impact on the efficiency of banks. Similarly, Profit/E of globalized banks is comparatively very high. Among these globalized new private sector banks, first comes the number of ICICI Bank followed by HDFC and Axis Banks. Profit/E of these banks is 9.72, 8.59 \& 8.06 respectively. Out of 5 globalized new private sector banks, two banks, namely, HDFC and ICICI Banks have very high, positive and significant correlation. Among non-globalized banks, although, two banks have positive correlation between BUS/E and Profit/E but it is not significant. 
Table 12: Business \& Profit per Employee of Partially Globalized and Non-Globalized NPSBs

\begin{tabular}{|c|c|c|c|c|c|c|c|}
\hline \multirow{2}{*}{$\begin{array}{l}\text { Name of Bank } \\
\text { Globalized Banks }\end{array}$} & \multicolumn{3}{|c|}{ Business/Employee } & \multicolumn{3}{|c|}{ Profit/Employee } & \multirow[t]{2}{*}{$\mathbf{r}$} \\
\hline & Mean & SD & CV & Mean & SD & CV & \\
\hline 1. Axis Bank & 949.17 & 88.39 & 9.31 & 8.06 & 0.38 & 4.71 & 0.094 \\
\hline $\begin{array}{l}\text { 2. Centurion Bank } \\
\text { of Punjab }\end{array}$ & 400.97 & 42.55 & 10.61 & 1.79 & 0.43 & 24.02 & -0.205 \\
\hline 3. HDFC Bank Ltd. & 780.00 & 95.62 & 12.26 & 8.59 & 1.53 & 17.81 & $0.888^{*}$ \\
\hline 4. ICICI Bank Ltd. & 904.75 & 222.67 & 24.61 & 9.72 & 2.38 & 24.49 & $0.842^{*}$ \\
\hline $\begin{array}{l}\text { 5. Induslnd Bank } \\
\text { Ltd. } \\
\text { Non-Globalized Banks }\end{array}$ & $\begin{array}{l}1132.8 \\
1\end{array}$ & 263.92 & 23.29 & 7.61 & 5.03 & 66.09 & 0.157 \\
\hline $\begin{array}{l}\text { 6. Development } \\
\text { Credit Bank Ltd. }\end{array}$ & 428.24 & 39.22 & 9.16 & -1.88 & 5.72 & -304.25 & 0.653 \\
\hline $\begin{array}{l}\text { 7. Kotak Mahindra } \\
\text { Bank Ltd. }\end{array}$ & 369.37 & 18.81 & 5.09 & 5.73 & 3.15 & 54.97 & -0.478 \\
\hline 8. Yes Bank Ltd. & 689.00 & 158.54 & 23.01 & 3.67 & 5.33 & 145.23 & 0.458 \\
\hline
\end{tabular}

Source: Same as table 11

Thus, the above discussion regarding the business and profit per employee of Indian globalized and nonglobalized banks exhibits the result that although even after so many years of the introduction of LPG policy, Indian banks lack behind in achieving the complete globalization but still Indian banking industry has potential to work successfully in global market.

Impact of IT on Productivity: IT has revolutionized the banking business ventured from brick to mortar and record superior performance. IT, along with other factors has remarkably affected all the factors affecting productivity. Concerns that IT is impact on different factors should be evaluated to draw the real picture. In due course, a correlation between e-channels and some selected factors of productivity is analyzed in a part that will enable to pick the most effectual echannel and what the change is observed in post-ebanking period over pre-ebanking period more particularly in partially IT-oriented banks.

Correlation Matrices for E-channels and Business per Employee: $G$-I (PSBs): Business per employee, an employee productivity factor, is highly correlated with different e-channels as is evidence from table 13 All the independent factors except $\mathrm{X}_{3}$ are significantly and positively correlated with business per employee $\left(\mathrm{Y}_{0}\right)$ a dependent factor where $X_{5}$ is the most effective one and explains 99.60 pc variations in business per employee during pre-ebanking period. In post-ebanking period, also all e-channels have positive and significant correlation with business per employee where also $\mathrm{X}_{5}$ is the most effective.

Table 13; Correlation Co-efficient Matrix for Business per Employee and Each e-channel (G - I)

\begin{tabular}{|c|c|c|c|c|c|c|c|c|c|}
\hline Period & Variables & $Y_{0}$ & $X_{1}$ & $X_{2}$ & $\mathbf{X}_{3}$ & $\mathbf{X}_{4}$ & $X_{5}$ & $X_{6}$ & $\mathbf{R}^{2}$ \\
\hline \multirow{7}{*}{$\begin{array}{l}\text { Pre } \\
\text { ebanking }\end{array}$} & $\mathrm{Y}_{0}$ & 1.00 & & & & & & & 1.0000 \\
\hline & $\mathrm{X}_{1}$ & $0.921 *$ & 1.00 & & & & & & 0.8482 \\
\hline & $\mathrm{X}_{2}$ & $0.941^{*}$ & $0.989 * *$ & 1.00 & & & & & 0.8855 \\
\hline & $\mathrm{X}_{3}$ & 0.866 & $0.969 * *$ & $0.972^{* *}$ & 1.00 & & & & 0.7500 \\
\hline & $\mathrm{X}_{4}$ & $0.991^{* *}$ & $0.912 *$ & $0.946^{*}$ & $0.886^{*}$ & 1.00 & & & 0.9821 \\
\hline & $\mathrm{X}_{5}$ & $0.998^{* *}$ & $0.923^{*}$ & $0.949 *$ & 0.872 & $0.994^{* *}$ & 1.00 & & 0.9960 \\
\hline & $X_{6}$ & $0.989^{* *}$ & $0.914^{*}$ & $0.952^{*}$ & 0.877 & $0.995^{* *}$ & $0.996^{* *}$ & 1.00 & 0.9781 \\
\hline \multirow{7}{*}{$\begin{array}{l}\text { Post - } \\
\text { ebanking }\end{array}$} & $\mathrm{Y}_{0}$ & 1.00 & & & & & & & 1.0000 \\
\hline & $\mathrm{X}_{1}$ & $0.928^{* *}$ & 1.00 & & & & & & 0.8612 \\
\hline & $\mathrm{X}_{2}$ & $0.965^{* *}$ & $0.830^{*}$ & 1.00 & & & & & 0.9312 \\
\hline & $\mathrm{X}_{3}$ & $0.871^{*}$ & 0.672 & $0.959^{* *}$ & 1.00 & & & & 0.7586 \\
\hline & $\mathrm{X}_{4}$ & $0.981^{* *}$ & $0.926^{* *}$ & $0.969^{* *}$ & $0.893^{*}$ & 1.00 & & & 0.9624 \\
\hline & $X_{5}$ & $0.995^{* *}$ & $0.892^{*}$ & $0.984^{* *}$ & $0.916^{*}$ & $0.982^{* *}$ & 1.00 & & 0.9900 \\
\hline & $X_{6}$ & $0.958^{* *}$ & $0.831 *$ & $0.996^{* *}$ & $0.968^{* *}$ & $0.974^{* *}$ & $0.980^{* *}$ & 1.00 & 0.9178 \\
\hline
\end{tabular}

Note: Correlation is significant at the 0.01 level (2-tailed) Correlation is significant at the 0.05 level (2-tailed) 
The important point to note that $\mathrm{X}_{3}$, insignificant in pre-ebanking period is significant in latter period. Postebanking period is testimony of higher correlation, Independent factors also have positive and significant correlation with each other during both study periods but higher in post-ebanking period confirms efficiency of IT, the most productive tool of transformation. G-II (OPSBS): G-II shows poor correlation between echannels and business per employee although it is positive in pre-ebanking period (table 14). $\mathrm{X}_{1}$ reports the highest effect explaining $99 \mathrm{pc}$ variations while $\mathrm{X}_{2} \& \mathrm{X}_{3}$ confirm insignificant correlation still positive. During post-ebanking period, an excellent improvement is observed because all the variables have positive and significant correlation with business per employee where $\mathrm{X}_{4}$ capture a look with the highest correlation and explains $97.02 \mathrm{pc}$ variations. It is worth mentioning that $\mathrm{X}_{2} \& \mathrm{X}_{3}$ are affecting the business at higher rates in second period proved by higher variations. Hence, post-ebanking period is the most effective and steady period witnessing the critical management of IT through improved performance with uppermost effect of internet banking though all e-channels are causing notable variations in business per employee. Independent variables also show higher correlation between each other during post-ebanking period.

Table 14: Correlation Co-efficient Matrix for Business per Employee and Each e-channel (G - II)

\begin{tabular}{|c|c|c|c|c|c|c|c|c|c|}
\hline Period & Variables & $Y_{0}$ & $X_{1}$ & $\mathrm{X}_{2}$ & $\mathbf{X}_{3}$ & $X_{4}$ & $\mathbf{X}_{5}$ & $\mathrm{X}_{6}$ & $\mathbf{R}^{2}$ \\
\hline \multirow{7}{*}{$\begin{array}{l}\text { Pre - } \\
\text { ebanking }\end{array}$} & $\mathrm{Y}_{0}$ & 1.00 & & & & & & & 1.0000 \\
\hline & $\mathrm{X}_{1}$ & $0.995^{* *}$ & 1.00 & & & & & & 0.9900 \\
\hline & $\mathrm{X}_{2}$ & 0.803 & 0.777 & 1.00 & & & & & 0.6448 \\
\hline & $\mathrm{X}_{3}$ & 0.858 & 0.839 & $0.994^{* *}$ & 1.00 & & & & 0.7362 \\
\hline & $\mathrm{X}_{4}$ & $0.938^{*}$ & $0.915^{*}$ & 0.858 & $0.886^{*}$ & 1.00 & & & 0.8798 \\
\hline & $\mathrm{X}_{5}$ & $0.898^{*}$ & 0.873 & $0.968^{* *}$ & $0.978^{* *}$ & $0.959^{* *}$ & 1.00 & & 0.8064 \\
\hline & $X_{6}$ & 0.929 & $0.905^{*}$ & $0.918^{*}$ & $0.938^{*}$ & $0.991^{* *}$ & $0.988^{* *}$ & 1.00 & 0.8630 \\
\hline \multirow{7}{*}{$\begin{array}{l}\text { Post - } \\
\text { ebanking }\end{array}$} & $Y_{0}$ & 1.00 & & & & & & & 1.0000 \\
\hline & $\mathrm{X}_{1}$ & $0.959^{* *}$ & 1.00 & & & & & & 0.9197 \\
\hline & $\mathrm{X}_{2}$ & $0.945^{* *}$ & $0.821^{*}$ & 1.00 & & & & & 0.8930 \\
\hline & $\mathrm{X}_{3}$ & $0.982^{* *}$ & $0.960^{* *}$ & $0.903^{*}$ & 1.00 & & & & 0.9643 \\
\hline & $\mathrm{X}_{4}$ & $0.985^{* *}$ & $0.975^{* *}$ & $0.885^{*}$ & $0.987^{* *}$ & 1.00 & & & 0.9702 \\
\hline & $X_{5}$ & $0.978^{* *}$ & $0.900^{*}$ & $0.946^{* *}$ & $0.975^{* *}$ & $0.968^{* *}$ & 1.00 & & 0.9565 \\
\hline & $\mathrm{X}_{6}$ & $0.981^{* *}$ & $0.895^{*}$ & $0.989^{* *}$ & $0.949^{* *}$ & $0.937^{* *}$ & $0.967^{* *}$ & 1.00 & 0.9624 \\
\hline
\end{tabular}

Note: Correlation is significant at the 0.01 level (2-tailed) Correlation is significant at the 0.05 level (2-tailed)

G-III (NPSBs): It can be seen in table 15 that all variables have insignificant impact on business per employee though positive where $X_{1}$ is not correlated because of constant nature as these banks have $100 \mathrm{pc}$ of their branches computerized from the starting of the business. $\mathrm{X}_{6}$ records the highest correlation although insignificant during pre-ebanking period.

Table 15: Correlation Co-efficient Matrix for Business per Employee and Each e-channel (G - III)

\begin{tabular}{|c|c|c|c|c|c|c|c|c|c|}
\hline Period & Variables & $Y_{0}$ & $X_{1}$ & $X_{2}$ & $X_{3}$ & $X_{4}$ & $X_{5}$ & $X_{6}$ & $\mathbf{R}^{2}$ \\
\hline \multirow{7}{*}{$\begin{array}{l}\text { Pre } \\
\text { ebanking }\end{array}$} & $\mathrm{Y}_{0}$ & 1.00 & & & & & & & 1.00 \\
\hline & $\mathrm{X}_{1}$ & $\mathrm{a}$ & 1.00 & & & & & & $\mathrm{a}$ \\
\hline & $\mathrm{X}_{2}$ & 0.436 & $\mathrm{a}$ & 1.00 & & & & & 0.1901 \\
\hline & $X_{3}$ & 0.173 & $\mathrm{a}$ & 0.850 & 1.00 & & & & 0.0299 \\
\hline & $\mathrm{X}_{4}$ & 0.316 & $\mathrm{a}$ & 0.438 & -0.024 & 1.00 & & & 0.0999 \\
\hline & $X_{5}$ & 0.429 & $\mathrm{a}$ & 0.419 & -0.052 & $0.990^{* *}$ & 1.00 & & 0.1840 \\
\hline & $X_{6}$ & 0.671 & $\mathrm{a}$ & 0.481 & 0.069 & $0.884^{*}$ & $0.935^{*}$ & 1.00 & 0.4502 \\
\hline \multirow{7}{*}{$\begin{array}{l}\text { Post } \\
\text { ebanking }\end{array}$} & $Y_{0}$ & 1.00 & & & & & & & 1.00 \\
\hline & $X_{1}$ & $\mathrm{a}$ & 1.00 & & & & & & $\mathrm{a}$ \\
\hline & $\mathrm{X}_{2}$ & -0.509 & $\mathrm{a}$ & 1.00 & & & & & 0.2591 \\
\hline & $\mathrm{X}_{3}$ & 0.503 & a & -0.035 & 1.00 & & & & 0.2530 \\
\hline & $\mathrm{X}_{4}$ & 0.318 & $\mathrm{a}$ & 0.162 & 0.754 & 1.00 & & & 0.1011 \\
\hline & $X_{5}$ & -0.070 & $\mathrm{a}$ & 0.531 & 0.532 & $0.880^{*}$ & 1.00 & & 0.0049 \\
\hline & $\mathrm{X}_{6}$ & 0.711 & $\mathrm{a}$ & -0.336 & $0.889 *$ & 0.443 & 0.097 & 1.00 & 0.5055 \\
\hline
\end{tabular}

Note: Correlation is significant at the 0.01 level (2-tailed) Correlation is significant at the 0.05 level (2-tailed) a Cannot be computed because at least one of the variables is constant 
Post-ebanking period discloses adverse consequences where $\mathrm{X}_{2} \& \mathrm{X}_{5}$ are negatively correlated with business per employee. Concerns that $\mathrm{X}_{6}$ is relatively more important caused the highest variations in business per employee during the whole study period. Correlation between independent variables is also insignificant except one or two like $\mathrm{X}_{4}$ with $\mathrm{X}_{5} \& \mathrm{X}_{6}$ and $\mathrm{X}_{5}$ with $\mathrm{X}_{6}$ in pre-ebanking period and $\mathrm{X}_{3}$ with $\mathrm{X}_{6}$ and $\mathrm{X}_{4}$ with $\mathrm{X}_{5}$ in latter period having significant correlation. Although, e-channels have no significant correlation with business per employee, but these are affecting each other significantly.

G-IV (FBs): Table 16 depicts that all variables have significant and positive correlation with business per employee during pre-ebanking period and $X_{2}$ is highly correlated causing 98.21 pc increase in business per employee with 1 pc more use of ATMs. During post-ebanking period, a record is unfavorable since all variables have negative though insignificant correlation with business per employee where $\mathrm{X}_{1}$ has no correlation because of constant nature of this factor as this group has all its branches computerized from the starting of the business. It is noteworthy that e-channels negate their impact on business per employee during the later period.

Table 16: Correlation Co-efficient Matrix for Business per Employee and Each e-channel (G - IV)

\begin{tabular}{|c|c|c|c|c|c|c|c|c|c|}
\hline Period & Variables & $Y_{0}$ & $X_{1}$ & $X_{2}$ & $X_{3}$ & $X_{4}$ & $X_{5}$ & $X_{6}$ & $\mathbf{R}^{2}$ \\
\hline \multirow{7}{*}{$\begin{array}{l}\text { Pre - } \\
\text { ebanking }\end{array}$} & $\mathrm{Y}_{0}$ & 1.00 & & & & & & & 1.0000 \\
\hline & $\mathrm{X}_{1}$ & $\mathrm{a}$ & 1.00 & & & & & & $\mathrm{a}$ \\
\hline & $X_{2}$ & $0.991^{* *}$ & $\mathrm{a}$ & 1.00 & & & & & 0.9821 \\
\hline & $X_{3}$ & $0.943^{*}$ & $\mathrm{a}$ & $0.892^{*}$ & 1.00 & & & & 0.8892 \\
\hline & $\mathrm{X}_{4}$ & $0.911^{*}$ & $\mathrm{a}$ & 0.851 & $0.995^{* *}$ & 1.00 & & & 0.8299 \\
\hline & $\mathrm{X}_{5}$ & $0.973^{* *}$ & $\mathrm{a}$ & $0.942 *$ & $0.970^{* *}$ & $0.958^{*}$ & 1.00 & & 0.9467 \\
\hline & $\mathrm{X}_{6}$ & $0.916^{*}$ & a & 0.863 & $0.981^{* *}$ & $0.988^{* *}$ & $0.977^{* *}$ & 1.00 & 0.8391 \\
\hline \multirow{7}{*}{$\begin{array}{l}\text { Post - } \\
\text { ebanking }\end{array}$} & $\mathrm{Y}_{0}$ & 1.00 & & & & & & & 1.0000 \\
\hline & $\mathrm{X}_{1}$ & $\mathrm{a}$ & 1.00 & & & & & & $\mathrm{a}$ \\
\hline & $\mathrm{X}_{2}$ & -0.534 & $\mathrm{a}$ & 1.00 & & & & & 0.2852 \\
\hline & $X_{3}$ & -0.615 & $\mathrm{a}$ & $0.839 *$ & 1.00 & & & & 0.3782 \\
\hline & $\mathrm{X}_{4}$ & -0.584 & $\mathrm{a}$ & $0.852^{*}$ & $0.969 * *$ & 1.00 & & & 0.3411 \\
\hline & $X_{5}$ & -0.657 & $\mathrm{a}$ & $0.907^{*}$ & $0.947^{* *}$ & $0.979 * *$ & 1.00 & & 0.4316 \\
\hline & $\mathrm{X}_{6}$ & -0.461 & $\mathrm{a}$ & 0.784 & $0.814^{*}$ & $0.932 * *$ & $0.919^{* *}$ & 1.00 & 0.2125 \\
\hline
\end{tabular}

Note: ** Correlation is significant at the 0.01 level (2-tailed)

* Correlation is significant at the 0.05 level (2-tailed)

A Cannot be computed because at least one of the variables is constant

Independent variables are affecting each other significantly during both the study periods where $\mathrm{X}_{4}$ records the highest correlation with $\mathrm{X}_{3}$ in pre-ebanking period and with $\mathrm{X}_{5}$ in post-ebanking period. All e-channels trim down business per employee though causing below 50 pc variations.

Industry: All bank groups collectively represent completely banking industry. Table 17 shows that all the variables except $\mathrm{X}_{2} \& \mathrm{X}_{6}$ have significant correlation with business per employee in pre-ebanking period where $\mathrm{X}_{4}$ is more important because it shows the highest correlation and explains $93.70 \mathrm{pc}$ variations in business per employee. During post-ebanking period, all variables apart from $\mathrm{X}_{1}$ are positively and significantly correlated with business per employee and $\mathrm{X}_{6}$ confirms the highest correlation. It is noteworthy that post-ebanking period substantiates greater correlation of $\mathrm{X}_{2} \& \mathrm{X}_{6}$ only whereas others witness downturn and among these tele-banking $\left(\mathrm{X}_{6}\right)$ is the most important factor explaining the highest variations in business per employee i.e. $88.17 \mathrm{pc}$. 
Table 17: Correlation Co-efficient Matrix for Business per Employee and Each e-channel (Industry)

\begin{tabular}{|c|c|c|c|c|c|c|c|c|c|}
\hline Period & Variables & $Y_{0}$ & $X_{1}$ & $X_{2}$ & $\mathbf{X}_{3}$ & $X_{4}$ & $X_{5}$ & $X_{6}$ & $\mathbf{R}^{2}$ \\
\hline \multirow{7}{*}{$\begin{array}{l}\text { Pre } \\
\text { ebanking }\end{array}$} & $\mathrm{Y}_{0}$ & 1.00 & & & & & & & 1.0000 \\
\hline & $\mathrm{X}_{1}$ & $0.952^{*}$ & 1.00 & & & & & & 0.9063 \\
\hline & $\mathrm{X}_{2}$ & 0.751 & 0.606 & 1.00 & & & & & 0.5640 \\
\hline & $\mathrm{X}_{3}$ & $0.908^{*}$ & 0.774 & $0.952^{*}$ & 1.00 & & & & 0.8245 \\
\hline & $\mathrm{X}_{4}$ & $0.968^{* *}$ & 0.866 & $0.885^{*}$ & $0.982^{* *}$ & 1.00 & & & 0.9370 \\
\hline & $\mathrm{X}_{5}$ & $0.951^{*}$ & $0.946^{*}$ & 0.781 & $0.890^{*}$ & 0.923* & 1.00 & & 0.9044 \\
\hline & $X_{6}$ & 0.871 & 0.729 & $0.975^{* *}$ & $0.996^{* *}$ & $0.964^{* *}$ & 0.859 & 1.00 & 0.7586 \\
\hline \multirow{7}{*}{$\begin{array}{l}\text { Post } \\
\text { ebanking }\end{array}$} & $\mathrm{Y}_{0}$ & 1.00 & & & & & & & 1.0000 \\
\hline & $\mathrm{X}_{1}$ & 0.765 & 1.00 & & & & & & 0.5852 \\
\hline & $\mathrm{X}_{2}$ & $0.937^{* *}$ & $0.905^{*}$ & 1.00 & & & & & 0.8780 \\
\hline & $\mathrm{X}_{3}$ & $0.881^{*}$ & $0.939 * *$ & $0.932^{* *}$ & 1.00 & & & & 0.7762 \\
\hline & $\mathrm{X}_{4}$ & $0.896^{*}$ & $0.938 * *$ & $0.974^{* *}$ & $0.920^{* *}$ & 1.00 & & & 0.8028 \\
\hline & $X_{5}$ & $0.925^{* *}$ & $0.932^{* *}$ & $0.977^{* *}$ & $0.941^{* *}$ & $0.996^{* *}$ & 1.00 & & 0.8556 \\
\hline & $X_{6}$ & $0.939 * *$ & $0.905^{*}$ & $0.979^{* *}$ & $0.922^{* *}$ & $0.993^{* *}$ & $0.997^{* *}$ & 1.00 & 0.8817 \\
\hline
\end{tabular}

Note: Correlation is significant at the 0.01 level (2-tailed) Correlation is significant at the 0.05 level (2-tailed)

Overall, e-channels have positive and significant correlation with business per employee except G-III in preebanking period but in post-ebanking period, only G-II, industry and I show higher correlation except for one or two variables whereas G-III \& IV wipe out the effect of all e-channels. Among all the bank groups, G-I evaluated as the most affected group by each e-channel in pre as well as post-ebanking period and mobile banking has affected its business at the most. Among all the e-channels, mobile banking affects the most relatively internet-banking, ATMs, computerized branches and tele banking has varied influence whereas credit cards do not have prominent affect.

\section{Impact of IT on Profitability}

Public Sector Banks (G-I): It can be seen from table 18 that profitability (a dependent factor) is negatively correlated with all e-channels and IT index $\left(\mathrm{X}_{7}\right)$ during pre-ebanking period where $\mathrm{X}_{1}$ is explaining the highest variations i.e. $46.10 \mathrm{pc}$ but independent variables are significantly correlated with each other where $\mathrm{X}_{5}$ is highly correlated with $\mathrm{X}_{6}$. During post-ebanking period, all the variable are continue to have negative affect on profitability although has a weak effect as compare to the last time period but computerized branches $\left(\mathrm{X}_{1}\right)$ is the only factor, that improves its effect from negative contribution in profitability during pre-ebanking period to positive in the later period.

Table 18: Correlation Co-efficient Matrix for Profitability and Each E-channel (G - I)

\begin{tabular}{|c|c|c|c|c|c|c|c|c|c|c|}
\hline Period & Variables & $Y_{1}$ & $\mathbf{X}_{1}$ & $\mathbf{X}_{2}$ & $\mathbf{X}_{3}$ & $\mathrm{X}_{4}$ & $X_{5}$ & $X_{6}$ & $\mathbf{X}_{7}$ & $\mathbf{R}^{2}$ \\
\hline \multirow{8}{*}{$\begin{array}{l}\text { Pre } \\
\text { ebanking }\end{array}$} & $\mathrm{Y}_{1}$ & 1.000 & & & & & & & & 1.0000 \\
\hline & $\mathrm{X}_{1}$ & -0.679 & 1.000 & & & & & & & 0.4610 \\
\hline & $\mathrm{X}_{2}$ & -0.570 & $0.989 * *$ & 1.000 & & & & & & 0.3249 \\
\hline & $\mathrm{X}_{3}$ & -0.529 & $0.969^{* *}$ & $0.972^{* *}$ & 1.000 & & & & & 0.2798 \\
\hline & $\mathrm{X}_{4}$ & -0.435 & $0.912^{*}$ & $0.946^{*}$ & $0.886^{*}$ & 1.000 & & & & 0.1892 \\
\hline & $\mathrm{X}_{5}$ & -0.506 & $0.923^{*}$ & $0.949 *$ & 0.872 & $0.994^{* *}$ & 1.000 & & & 0.2560 \\
\hline & $X_{6}$ & -0.444 & $0.914^{*}$ & $0.952^{*}$ & 0.877 & $0.995^{* *}$ & $0.996^{* *}$ & 1.000 & & 0.1971 \\
\hline & $X_{7}$ & -0.157 & 0.784 & 0.827 & $0.904 *$ & 0.808 & 0.750 & 0.774 & 1.000 & 0.0246 \\
\hline \multirow{8}{*}{$\begin{array}{l}\text { Post } \\
\text { ebanking }\end{array}$} & $Y_{1}$ & 1.000 & & & & & & & & 1.0000 \\
\hline & $\mathrm{X}_{1}$ & 0.098 & 1.000 & & & & & & & 0.0096 \\
\hline & $\mathrm{X}_{2}$ & -0.120 & $0.830 *$ & 1.000 & & & & & & 0.0144 \\
\hline & $X_{3}$ & -0.157 & 0.672 & $0.959^{* *}$ & 1.000 & & & & & 0.0246 \\
\hline & $\mathrm{X}_{4}$ & 0.021 & $0.926^{* *}$ & $0.969^{* *}$ & $0.893^{*}$ & 1.000 & & & & 0.0004 \\
\hline & $X_{5}$ & -0.161 & $0.892 *$ & $0.984 * *$ & $0.916^{*}$ & $0.982^{* *}$ & 1.000 & & & 0.0259 \\
\hline & $\mathrm{X}_{6}$ & -0.075 & $0.831^{*}$ & $0.996^{* *}$ & $0.968^{* *}$ & $0.974^{* *}$ & $0.980^{* *}$ & 1.000 & & 0.0056 \\
\hline & $\mathrm{X}_{7}$ & -0.030 & $0.948^{* *}$ & $0.963^{* *}$ & $0.868^{*}$ & $0.995^{* *}$ & $0.987^{* *}$ & $0.963^{* *}$ & 1.000 & 0.0009 \\
\hline
\end{tabular}

Note: ** Correlation is significant at the 0.01 level (2-tailed)

* Correlation is significant at the 0.05 level (2-tailed) 
Here also, all independent variables have significant positive correlation with each other where $\mathrm{X}_{2}$ is highly correlated with $\mathrm{X}_{6}$. It is concluded that post-ebanking period witnesses an improvement in the e-channels' effect on profitability of public sector banks but still have negative contribution and only computerized branches is the variable contributing positively.

Old private Sector Banks (G-II): Table 19 bring to light that profitability of G-II is negatively but insignificantly correlated with all the independent variables except $\mathrm{X}_{4}$ where $\mathrm{X}_{7}$ (IT Index) proves the highest variations $(42.51 \mathrm{pc})$ in profitability. It is important to note that all the individual e-channels have significant positive correlation with each other except IT index, where $\mathrm{X}_{2}$ is highly correlated with $\mathrm{X}_{3}$. All e-channels continue to have insignificant but negative correlation with profitability even records higher variations and $\mathrm{X}_{1}$ is an important variable because it is explaining $48.30 \mathrm{pc}$ variations in profitability. $\mathrm{X}_{4}$ draws an attention because it has positively contributed towards profitability in pre-ebanking period but is effecting negatively (27.88 pc) during the later period. All the independent variables have significant positive correlation with each other where $\mathrm{X}_{2}$ is much important because it explains the highest correlation with $\mathrm{X}_{6}$. It is concluded from the data that IT is affecting the profitability of old private sector banks negatively.

Table 19: Correlation Co-efficient Matrix for Profitability and Each E-channel (G - II)

\begin{tabular}{|c|c|c|c|c|c|c|c|c|c|c|}
\hline Period & Variables & $Y_{1}$ & $X_{1}$ & $X_{2}$ & $\mathbf{X}_{3}$ & $X_{4}$ & $X_{5}$ & $X_{6}$ & $\mathbf{X}_{7}$ & $\mathbf{R}^{2}$ \\
\hline \multirow{8}{*}{$\begin{array}{l}\text { Pre } \\
\text { ebanking }\end{array}$} & $\mathrm{Y}_{1}$ & 1.000 & & & & & & & & 1.0000 \\
\hline & $\mathrm{X}_{1}$ & $\overline{0}-263$ & 1.000 & & & & & & & 0.0692 \\
\hline & $\mathrm{X}_{2}$ & $\begin{array}{l}- \\
0.207\end{array}$ & 0.777 & 1.000 & & & & & & 0.0428 \\
\hline & $\mathrm{X}_{3}$ & $\overline{0} .239$ & 0.839 & $0.994^{* *}$ & 1.000 & & & & & 0.0571 \\
\hline & $\mathrm{X}_{4}$ & 0.043 & $0.915^{*}$ & 0.858 & $0.886^{*}$ & 1.000 & & & & 0.0018 \\
\hline & $\mathrm{X}_{5}$ & $\begin{array}{l}- \\
0.094\end{array}$ & 0.873 & $0.968^{* *}$ & $0.978^{* *}$ & $0.959^{* *}$ & 1.000 & & & 0.0088 \\
\hline & $\mathrm{X}_{6}$ & $\overline{-} .020$ & $0.905^{*}$ & $0.918^{*}$ & $0.938^{*}$ & $0.991^{* *}$ & $0.988^{* *}$ & 1.000 & & 0.0004 \\
\hline & $\mathrm{X}_{7}$ & $\begin{array}{l}- \\
0.652\end{array}$ & 0.692 & 0.386 & 0.444 & 0.502 & 0.457 & 0.486 & 1.000 & 0.4251 \\
\hline \multirow{8}{*}{$\begin{array}{l}\text { Post - } \\
\text { ebanking }\end{array}$} & $\mathrm{Y}_{1}$ & 1.000 & & & & & & & & 1.0000 \\
\hline & $\mathrm{X}_{1}$ & 0.695 & 1.000 & & & & & & & 0.4830 \\
\hline & $\mathrm{X}_{2}$ & $\overline{0}-406$ & $0.821^{*}$ & 1.000 & & & & & & 0.1648 \\
\hline & $\mathrm{X}_{3}$ & $\overline{0}-533$ & $0.960^{* *}$ & $0.903^{*}$ & 1.000 & & & & & 0.2841 \\
\hline & $\mathrm{X}_{4}$ & $\begin{array}{l}- \\
0.528\end{array}$ & $0.975^{* *}$ & $0.885^{*}$ & $0.987^{* *}$ & 1.000 & & & & 0.2788 \\
\hline & $\mathrm{X}_{5}$ & $\overline{-}-381$ & $0.900^{*}$ & $0.946^{* *}$ & $0.975^{* *}$ & $0.968^{* *}$ & 1.000 & & & 0.1452 \\
\hline & $\mathrm{X}_{6}$ & $\begin{array}{l}- \\
0.502\end{array}$ & $0.895^{*}$ & $0.989^{* *}$ & $0.949^{* *}$ & $0.937^{* *}$ & $0.967^{* *}$ & 1.000 & & 0.2520 \\
\hline & $\mathrm{X}_{7}$ & $\begin{array}{l}- \\
0.589\end{array}$ & $0.970^{* *}$ & $0.924^{* *}$ & $0.967^{* *}$ & $0.983^{* *}$ & $0.951^{* *}$ & $0.966^{* *}$ & 1.000 & 0.3469 \\
\hline
\end{tabular}

Note: ${ }^{*}$ Correlation is significant at the 0.01 level (2-tailed), * Correlation is significant at the 0.05 level $(2$ tailed)

New Private Sector Banks (G-III): It is clear from table 20 that some variables like $\mathrm{X}_{4}, \mathrm{X}_{5}, \mathrm{X}_{6}$ and $\mathrm{X}_{7}$ have significant negative correlation with profitability where $X_{2}$ and $X_{3}$ have insignificant negative correlation in pre-ebanking period. Among all the variables, $X_{5}$ draw an attention because 1 pc increase in mobile-banking services leads $96.04 \mathrm{pc}$ decreases in profitability. Only few variables like $\mathrm{X}_{4}, \mathrm{X}_{5}$, and $\mathrm{X}_{6}$ have significant positive correlation with other independent variables where $\mathrm{X}_{4}$ proves the highest correlation with $\mathrm{X}_{5}$. During post- 
ebanking, $\mathrm{X}_{4}$ and $\mathrm{X}_{5}$ continue to have negative but insignificant correlation with profitability whereas other variables have improved their impact from negative in pre-ebanking to positive in the later period although the effect is weak. $\mathrm{X}_{6}$ is the most significance variable enhancing the profitability of new private sector banks.

Table 20: Correlation Co-efficient Matrix for Profitability and Each E-channel (G - III)

\begin{tabular}{|c|c|c|c|c|c|c|c|c|c|c|}
\hline Period & Variables & $Y_{1}$ & $X_{1}$ & $X_{2}$ & $\mathbf{X}_{3}$ & $\mathbf{X}_{4}$ & $X_{5}$ & $X_{6}$ & $X_{7}$ & $\mathbf{R}^{2}$ \\
\hline \multirow{8}{*}{$\begin{array}{l}\text { Pre } \\
\text { ebanking }\end{array}$} & $\mathrm{Y}_{1}$ & 1.000 & & & & & & & & 1.0000 \\
\hline & $\mathrm{X}_{1}$ & $\mathrm{a}$ & a & & & & & & & $\mathrm{a}$ \\
\hline & $\mathrm{X}_{2}$ & -0.560 & $\mathrm{a}$ & 1.000 & & & & & & 0.3136 \\
\hline & $X_{3}$ & -0.077 & a & 0.850 & 1.000 & & & & & 0.0059 \\
\hline & $\mathrm{X}_{4}$ & $-0.970 * *$ & $a$ & 0.438 & -0.024 & 1.000 & & & & 0.9409 \\
\hline & $\mathrm{X}_{5}$ & $-0.980 * *$ & $\mathrm{a}$ & 0.419 & -0.052 & $0.990^{* *}$ & 1.000 & & & 0.9604 \\
\hline & $\mathrm{X}_{6}$ & $-0.931^{*}$ & $\mathrm{a}$ & 0.481 & 0.069 & $0.884^{*}$ & $0.935^{*}$ & 1.000 & & 0.8668 \\
\hline & $X_{7}$ & $-0.940 *$ & $a$ & 0.635 & 0.266 & $0.941^{*}$ & $0.939 *$ & $0.918^{*}$ & 1.000 & 0.8836 \\
\hline \multirow{8}{*}{$\begin{array}{l}\text { Post - } \\
\text { ebanking }\end{array}$} & $Y_{1}$ & 1.000 & & & & & & & & 1.0000 \\
\hline & $X_{1}$ & $\mathrm{a}$ & $\mathrm{a}$ & & & & & & & $\mathrm{a}$ \\
\hline & $X_{2}$ & 0.171 & a & 1.000 & & & & & & 0.0292 \\
\hline & $\mathrm{X}_{3}$ & 0.151 & $\mathrm{a}$ & -0.035 & 1.000 & & & & & 0.0228 \\
\hline & $\mathrm{X}_{4}$ & -0.087 & $\mathrm{a}$ & 0.162 & 0.754 & 1.000 & & & & 0.0076 \\
\hline & $X_{5}$ & -0.205 & $\mathrm{a}$ & 0.531 & 0.532 & $0.880^{*}$ & 1.000 & & & 0.0420 \\
\hline & $\mathrm{X}_{6}$ & 0.258 & $\mathrm{a}$ & -0.336 & $0.889 *$ & 0.443 & 0.097 & 1.000 & & 0.0666 \\
\hline & $X_{7}$ & 0.173 & $\mathrm{a}$ & 0.647 & 0.688 & 0.803 & $0.860^{*}$ & 0.362 & 1.000 & 0.0299 \\
\hline
\end{tabular}

Note: ${ }^{* *}$ Correlation is significant at the 0.01 level (2-tailed), ${ }^{*}$ Correlation is significant at the 0.05 level $(2$ tailed, a Cannot be computed because at least one of the variables is constant

Foreign Banks (G-IV): It can be seen from table 21 that $\mathrm{X}_{2}$ is the only variable which has significant but negative correlation causing 78.85 pc decline in profitability while other variables have insignificant though negative effect on banks' profitability in pre-ebanking period. All the independent variables have positive and significant correlation with each other where $\mathrm{X}_{5}$ is highly correlated with $\mathrm{X}_{7}$. During post-ebanking period, all the variables show excellent improvement in their effect on profitability from negative contribution in preebanking period to positive in the later period. It is concluded that all the e-channels have improved their contribution from negative to positive in banks profitability where $\mathrm{X}_{2}$ is the most important variable that contributes to enhance the profitability at a large and post-ebanking period confirms the positive improvement of its contribution in banks' profitability that further proves positive effect of bank transformation.

Table 21: Correlation Co-efficient Matrix for Profitability and Each E-channel (G - IV)

\begin{tabular}{|c|c|c|c|c|c|c|c|c|c|c|}
\hline Period & Variables & $Y_{1}$ & $\mathbf{X}_{1}$ & $X_{2}$ & $\mathbf{X}_{3}$ & $\mathbf{X}_{4}$ & $\mathbf{X}_{5}$ & $X_{6}$ & $X_{7}$ & $\mathbf{R}^{2}$ \\
\hline \multirow{8}{*}{$\begin{array}{l}\text { Pre } \\
\text { ebanking }\end{array}$} & $\mathrm{Y}_{1}$ & 1.000 & & & & & & & & 1.0000 \\
\hline & $\mathrm{X}_{1}$ & $\mathrm{a}$ & $\mathrm{a}$ & & & & & & & $\mathrm{a}$ \\
\hline & $\mathrm{X}_{2}$ & $-.0888 *$ & a & 1.000 & & & & & & 0.7885 \\
\hline & $X_{3}$ & -0.729 & $\mathrm{a}$ & $0.892^{*}$ & 1.000 & & & & & 0.5314 \\
\hline & $\mathrm{X}_{4}$ & -0.689 & $\mathrm{a}$ & 0.851 & $0.995^{* *}$ & 1.000 & & & & 0.4747 \\
\hline & $\mathrm{X}_{5}$ & -0.866 & $\mathrm{a}$ & $0.942^{*}$ & $0.970^{* *}$ & $0.958^{*}$ & 1.000 & & & 0.7500 \\
\hline & $\mathrm{X}_{6}$ & -0.754 & $\mathrm{a}$ & 0.863 & $0.981^{* *}$ & $0.988^{* *}$ & $0.977^{* *}$ & 1.000 & & 0.5685 \\
\hline & $\mathrm{X}_{7}$ & -0.817 & $\mathrm{a}$ & $0.937^{*}$ & $0.986^{* *}$ & $0.976^{* *}$ & $0.995^{* *}$ & $0.985^{* *}$ & 1.000 & 0.6675 \\
\hline \multirow{8}{*}{$\begin{array}{l}\text { Post } \quad- \\
\text { ebanking }\end{array}$} & $\mathrm{Y}_{1}$ & 1.000 & & & & & & & & 1.0000 \\
\hline & $\mathrm{X}_{1}$ & $\mathrm{a}$ & $\mathrm{a}$ & & & & & & & $\mathrm{a}$ \\
\hline & $\mathrm{X}_{2}$ & 0.522 & $\mathrm{a}$ & 1.000 & & & & & & 0.2725 \\
\hline & $X_{3}$ & 0.109 & $\mathrm{a}$ & $0.839 *$ & 1.000 & & & & & 0.0119 \\
\hline & $\mathrm{X}_{4}$ & 0.083 & $\mathrm{a}$ & $0.852^{*}$ & $0.969^{* *}$ & 1.000 & & & & 0.0069 \\
\hline & $X_{5}$ & 0.258 & $\mathrm{a}$ & $0.907 *$ & $0.947^{* *}$ & $0.979 * *$ & 1.000 & & & 0.0666 \\
\hline & $\mathrm{X}_{6}$ & 0.066 & $\mathrm{a}$ & 0.784 & $0.814^{*}$ & $0.932^{* *}$ & $0.919^{* *}$ & 1.000 & & 0.0044 \\
\hline & $\mathrm{X}_{7}$ & 0.325 & $\mathrm{a}$ & $0.943^{* *}$ & $0.879 *$ & $0.947^{* *}$ & $0.975^{* *}$ & $0.944^{* *}$ & 1.000 & 0.1056 \\
\hline
\end{tabular}

Note: ** Correlation is significant at the 0.01 level (2-tailed), * Correlation is significant at the 0.05 level (2tailed), a Cannot be computed because at least one of the variables is constant 
Industry: Industry, in table 22, also shows negative but insignificant correlation between all e-channels and profitability in pre-ebanking period where $\mathrm{X}_{5}$ draw an attention by explaining 50.13 pc variations in profitability of the industry. All independent variables have significant positive correlation with each other and $\mathrm{X}_{3}$ is highly correlated with $\mathrm{X}_{6}$ while $\mathrm{X}_{1}$ is the only variable that has insignificant relationship with others. During post-ebanking period, all the variables have increased their significance because their effect is changed from negative in pre-ebanking period to positive contribution in post-ebanking period and $\mathrm{X}_{3}$ is more important which explains $15.68 \mathrm{pc}$ variations in profitability whereas independent variables have higher and significant correlation with each other. It is important to note that IT has improved its effect on profitability from $12.11 \mathrm{pc}$ negative to $1.59 \mathrm{pc}$ positive through out the study period.

Table 22: Correlation Co-efficient Matrix for Profitability and Each E-channel (Industry)

\begin{tabular}{|c|c|c|c|c|c|c|c|c|c|c|}
\hline Period & Variables & $Y_{1}$ & $X_{1}$ & $X_{2}$ & $X_{3}$ & $X_{4}$ & $X_{5}$ & $X_{6}$ & $X_{7}$ & $\mathbf{R}^{2}$ \\
\hline \multirow{8}{*}{$\begin{array}{l}\text { Pre - } \\
\text { ebanking }\end{array}$} & $\mathrm{Y}_{1}$ & 1.000 & & & & & & & & 1.0000 \\
\hline & $\mathrm{X}_{1}$ & $\overline{-}-686$ & 1.000 & & & & & & & 0.4706 \\
\hline & $X_{2}$ & $\overline{-} 0.295$ & 0.606 & 1.000 & & & & & & 0.0870 \\
\hline & $X_{3}$ & 0.524 & 0.774 & $0.952^{*}$ & 1.000 & & & & & 0.2746 \\
\hline & $\mathrm{X}_{4}$ & $-\overline{-}-582$ & 0.866 & $0.885^{*}$ & $0.982^{* *}$ & 1.000 & & & & 0.3387 \\
\hline & $X_{5}$ & $\overline{0} .708$ & $0.946^{*}$ & 0.781 & $0.890^{*}$ & $0.923^{*}$ & 1.000 & & & 0.5013 \\
\hline & $\mathrm{X}_{6}$ & $\overline{0}-448$ & 0.729 & $0.975^{* *}$ & $0.996^{* *}$ & $0.964^{* *}$ & 0.859 & 1.000 & & 0.2007 \\
\hline & $\mathrm{X}_{7}$ & $\overline{-}-348$ & 0.684 & $0.990^{* *}$ & $0.979^{* *}$ & $0.936^{*}$ & 0.822 & $0.993^{* *}$ & 1.000 & 0.1211 \\
\hline \multirow{8}{*}{$\begin{array}{l}\text { Post - } \\
\text { ebanking }\end{array}$} & $Y_{1}$ & 1.000 & & & & & & & & 1.0000 \\
\hline & $\mathrm{X}_{1}$ & 0.261 & 1.000 & & & & & & & 0.0681 \\
\hline & $\mathrm{X}_{2}$ & 0.049 & $0.905^{*}$ & 1.000 & & & & & & 0.0024 \\
\hline & $X_{3}$ & 0.396 & $0.939 * *$ & $0.932^{* *}$ & 1.000 & & & & & 0.1568 \\
\hline & $\mathrm{X}_{4}$ & 0.030 & $0.938^{* *}$ & $0.974^{* *}$ & $0.920^{* *}$ & 1.000 & & & & 0.0009 \\
\hline & $\mathrm{X}_{5}$ & 0.088 & $0.932^{* *}$ & $0.977^{* *}$ & $0.941^{* *}$ & $0.996^{* *}$ & 1.000 & & & 0.0077 \\
\hline & $\mathrm{X}_{6}$ & 0.035 & $0.905^{*}$ & $0.979 * *$ & $0.922^{* *}$ & $0.993^{* *}$ & $0.997^{* *}$ & 1.000 & & 0.0012 \\
\hline & $\mathrm{X}_{7}$ & 0.126 & 0.789 & $0.949 * *$ & $0.903^{*}$ & $0.901^{*}$ & $0.931^{* *}$ & $0.941^{* *}$ & 1.000 & 0.0159 \\
\hline
\end{tabular}

Note: ${ }^{* *}$ Correlation is significant at the 0.01 level (2-tailed)

* Correlation is significant at the 0.05 level (2-tailed)

Trends in Next 20 Years: More specifically the following trends are envisioned in the next 20 years:

- Technology will be the prime driver of changes. These include computers, communications and electronics.

- Global interdependence to increase.

- The increasing integration of world economy to result in decline of US economy.

- English to emerge as principal global language.

- Speculator growth of on-line banking.

- Digital signatures will be accepted in most countries.

- Internationally recognized "Smart Cards" to bring the world closer to global currency.

- Service sector to drive growth of development countries.

- Rural areas also networked facilitating real-time financial transactions.

- Role of brick-and-mortar network restricted to rural areas

- Bank staff to have multi-disciplinary skills

- Significant investment in electronic customer relationship management.

- Substantial reduction in low skilled work force in banks. 
- Switching of accounting from one bank to another through a mouse-click.

Areas of future comprehensive research: There is an urgent need for comprehensive research in the following areas

- Service quality in traditional and IT oriented banks

- E-services in rural areas

- Strategies for mind-set change about technology

- Per transaction cost in manual system as well as in e banks

\section{Conclusion}

The paper concludes that information technology in the banking industry has revolutionized the banking services. It is cost effective and time practical understanding. It can be seen in banking industry the productivity and profitability has been improved in post-ebanking period as compared to per-ebanking period, but still Indian banks have less profitability as compared to foreign banks. The Indian banks are ready to enter in the foreign markets. Therefore, the Indian banking industry adopts new revolutionary changes. This will be true of the financial service industry because the revolutionary change will come in the financial industry eventually. The successful organization in such scenario will be ones who have future thinkers those who can think for ahead and constantly challenge the assumption about the future.

\section{References}

Af-Tamini, H. A. H. \& Iabnoun, N. (2006). Service Quality of Bank Performance: A Comparison of the UAE National Foreign Banks. Finance India, 20(1), 181-197.

Kumar, T. S. (2006). Leveraging Technology Foreign Banks Financial Inclusion. Bankers Conference Proceedings, 144-152.

Laxman, R., Deene, S. \& Badiger, S. (2008). Changing Dimensions of Banking Sector in India, edited book by Dr. R.K Uppal: Paradigm Shift in Indian Banking, 70-80.

Lal, R. C. (2007). Banking Transformation through IT in India. Journal of Commerce and Trade, 2(2), 46-48.

Madhavankutty, G. (2007). Indian Banking-Towards Global Best Practices, Bankers Conference Proceedings (Nov.), 84-86.

Muniappan, G. P. (2002). Indian Banking: Paradigm Shift -A Regular Point of View. IBA Bulletin, 24(3), 151155.

Nair, K. N. C. (2006). Relying on Technology to meet $21^{\text {st }}$ Century Challenges, Contributions, II, and Bank net India, (September), 6-11.

Singla, H. K. (2008). Financial Performance of Banks in India. The ICFAI Journal of Bank Management, 7(1), 5062.

Shroff, F. T. (2007). Modern Banking Technology, Contributors. Bank net Publications, 4, 44-49.

Subbaroo, P. S. (2007). Changing Paradigm in Indian Banking, Gyan Management, 2, 151-160.

Tiwari, S. (2005). Development Financial Institutions \& Indian Banking: A Paradigm Shift. Punjab Journal of Business Studies, 1(1), 38-45.

Uppal, R. K. \& Kaur, R. (2007). Indian Banking Industry: Comparative Performance Evaluation in the Liberalized and Globalized Era. Gyan Management, 2, 3-24. 